\section{(A) Check for updates}

Cite this: Org. Biomol. Chem., 2017, 15,6984

\title{
Phenothiazine-linked nucleosides and nucleotides for redox labelling of DNA $\dagger$
}

\author{
Anna Simonova, ${ }^{a}$ Luděk Havran, ${ }^{\mathrm{b}}$ Radek Pohl, ${ }^{a}$ Miroslav Fojta*b,c and \\ Michal Hocek iD *a,d
}

\begin{abstract}
Nucleosides and 2'-deoxyribonucleoside triphosphates (dNTPs) bearing phenothiazine (PT) attached to a nucleobase (cytosine or 7-deazaadenine) either directly or through an acetylene linker were prepared through Suzuki or Sonogashira cross-coupling and triphosphorylation, and were studied as building blocks for polymerase construction of modified DNA. The directly PT-substituted dNTPs were better substrates for polymerases than the alkyne-linked dNTPs but all of them were used in enzymatic synthesis of DNA using primer extension, nicking enzyme amplification, PCR or 3'-tail labelling by terminal deoxynucleotidyl transferase. The phenothiazine served as an oxidizable redox label (giving two analytically useful signals of oxidation on electrode) for nucleosides and DNA and was also used in orthogonal combination with previously developed benzofurazane or nitrophenyl labels for redox coding of DNA bases. Therefore, the title PT-linked dNTPs are useful additions to the portfolio of nucleotides for enzymatic synthesis of redox-labelled DNA for electrochemical analysis.
\end{abstract}

Received 14th June 2017, Accepted 26th July 2017

DOI: $10.1039 / c 70 b 01439 b$ rsc.li/obc ation of some labels into DNA. More recently, we reported the first orthogonal and ratiometric set of two reducible labels (nitrophenyl and benzofurazane) useful for electrochemical minisequencing of short DNA stretches. ${ }^{9}$ However, we need a set of at least four fully orthogonal labels for diagnostic applications and, given the rather narrow window of potentials available for electrochemical analysis of DNA, we should be able to combine some reducible and some oxidizable labels. While previously developed reducible labels, i.e. nitrophenyl, ${ }^{5}$ benzofurazane ${ }^{9}$ or azidophenyl, ${ }^{10}$ give strong signals due to multi-electron reductions, most of the oxidizable labels ${ }^{3,14}$ typically gave weak signals due to one-electron oxidation. Therefore, there is a great need for other oxidizable labels for DNA and we turned our attention to phenothiazine (PT).

PT derivatives are known redox-active molecules giving either two waves of single electron oxidations ${ }^{15}$ or one strong two-electron oxidation. ${ }^{16,17}$ They have been extensively used as redox and fluorescent label for polymers and other compounds. ${ }^{18,19}$ Some PT derivatives have also been used for labelling of nucleic acids, mostly for photosensitizing ${ }^{20}$ or chargetransfer study. ${ }^{21-24}$ One example of a PT-linked dNTP (through a flexible non-conjugate amide linker) was shown in a recent work $^{12}$ for polymerase labelling of DNA and for redox coding in a single-nucleotide polymorphism study. However, the PTlinked dNTP was not fully characterized and the biochemistry of the enzymatic incorporation was not reported either. ${ }^{12}$ Therefore, we decided to prepare a set of PTZ-modified nucleosides and dNTPs either directly linked or tethered through a conjugate acetylene linker and characterize them chemically, 
electrochemically and biochemically in order to develop them as useful redox labels for DNA.

\section{Results and discussion}

\section{Synthesis}

From previous studies it is well known that dNTPs bearing modifications at position 5 of pyrimidines or at position 7 of 7 deazapurines are good substrates for DNA polymerases ${ }^{25,26}$ and some dNTPs bearing less bulky aryl or alkynyl groups can even be better substrates than natural dNTPs. ${ }^{27-29}$ Therefore, we selected 2'-deoxycytidine linked through position 5 and 2'-deoxy-7-deazaadenine linked through position 7 for attachment of PT either directly via s single bond or through a conjugate ethynyl tether. The syntheses started from commercial 2'-deoxy-5-iodocytidine (dC $\left.{ }^{\mathbf{I}}\right)$ or from well-known 2'-deoxy-7iodo-7-deazaadenosine ( $\left.\mathbf{d A}^{\mathbf{I}}\right),{ }^{30}$ which were triphosphorylated to the corresponding dNTPs (dC ${ }^{\mathbf{I}} \mathbf{T P}$ and $\left.\mathbf{d} \mathbf{A}^{\mathbf{I}} \mathbf{T P}\right){ }^{5}$ The SuzukiMiyaura cross-coupling of iodinated nucleosides $\left(\mathbf{d C}^{\mathbf{I}}\right.$ or $\left.\mathbf{d A}^{\mathbf{I}}\right)$ with PTZ-linked pinacolborane 1 under aqueous conditions ${ }^{31}$ in the presence of $\mathrm{Pd}(\mathrm{OAc})_{2}$ and tris(3-sulfonatophenyl)phosphine (TPPTS) gave the arylated nucleosides $\left(\mathbf{d C}^{\mathbf{P T}}\right.$ and $\left.\mathbf{d A} \mathbf{A}^{\mathbf{P T}}\right)$ in good yields of $75 \%$ or $96 \%$, respectively (Scheme 1, Table 1). The Sonogashira cross-coupling reactions of $\mathbf{d C}^{\mathbf{I}}$ or $\mathbf{d} \mathbf{A}^{\mathbf{I}}$ with ethynylphenothiazine 2 were performed in the presence of $\mathrm{Pd}$ $\left(\mathrm{PPh}_{3}\right)_{2} \mathrm{Cl}_{2}$ and $\mathrm{CuI}$ in DMF to give labelled nucleosides $\mathbf{d C} \mathbf{C P T}^{\mathbf{E P T}}$ and $\mathbf{d A}^{\mathbf{E P T}}$ in similarly good yields (76\% and 93\%). The Suzuki-Miyaura reactions of iodinated $\mathbf{d N}^{\mathbf{I}} \mathbf{T P s}$ with PT-Bpin (1) under aqueous conditions gave the desired PT-linked $\mathbf{d N}^{\mathbf{P T}} \mathbf{T P s}\left(\mathbf{d C}^{\mathbf{P T}} \mathbf{T P}\right.$ in $53 \%$ and $\mathbf{d A}^{\mathbf{P T}} \mathbf{T P}$ in $68 \%$ ), whereas the aqueous Sonogashira reactions of $\mathbf{d N} \mathbf{N}^{\mathbf{I}} \mathbf{T P s}$ with EPT (2) afforded the PT-acetylene-linked $\mathbf{d N}^{\mathbf{E P T}} \mathbf{T P s}\left(\mathbf{d C}^{\mathbf{E P T}} \mathbf{T P}\right.$ in $48 \%$ and $\mathbf{d} \mathbf{A}^{\mathbf{E P T}} \mathbf{T P}$ in $49 \%$ ). Taking into account partial hydrolysis of the dNTPs during the reaction and isolation, these yields are very good. Alternatively, the $\mathbf{d N}^{\mathbf{E P T}} \mathbf{T P s}$ were prepared by triphosphorylation of the corresponding nucleosides $\mathbf{d N}^{\mathbf{E P T}}$ in moderate yields (43 and $45 \%$ ). In all cases the PT-labelled $\mathbf{d N}^{\mathbf{P T}} \mathbf{T P S}$ or $\mathbf{d N}^{\mathbf{E P T}}$ TPs were isolated in ca. $30-60 \mathrm{mg}$ amounts by HPLC and fully characterized.

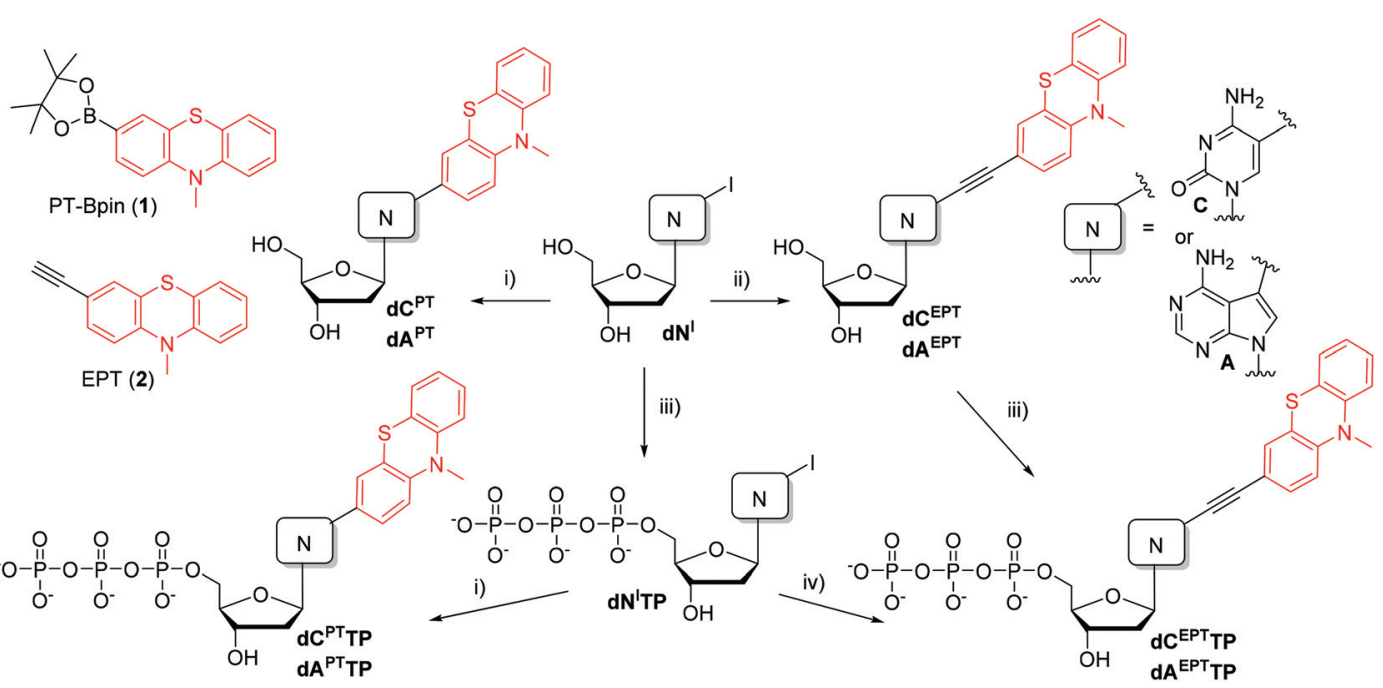

Scheme 1 Reagents and conditions: (i) PT-Bpin (1), Pd(OAc) $)_{2}, T_{P P T S}, \mathrm{Cs}_{2} \mathrm{CO}_{3}, \mathrm{AN} / \mathrm{H}_{2} \mathrm{O}(1: 1), 50{ }^{\circ} \mathrm{C}, 40 \mathrm{~min}$; (ii) $\mathrm{EPT}(2), \mathrm{Pd}(\mathrm{PPh})_{2} \mathrm{Cl}{ }_{2}, \mathrm{Cul}, \mathrm{Et}{ }_{3} \mathrm{~N}$, DMF, $75{ }^{\circ} \mathrm{C}, 1 \mathrm{~h}$; (iii) $1 . \mathrm{POCl}_{3}, \mathrm{PO}(\mathrm{OMe})_{3}, 0{ }^{\circ} \mathrm{C}, 3 \mathrm{~h}$; 2. $\left(\mathrm{NHBu}_{3}\right)_{2} \mathrm{H}_{2} \mathrm{P}_{2} \mathrm{O}_{7}, \mathrm{Bu}_{3} \mathrm{~N}, \mathrm{DMF}, 0{ }^{\circ} \mathrm{C}, 1.5 \mathrm{~h}$; 3 . TEAB; (iv) EPT (2), Pd(OAc) ${ }_{2}, \mathrm{Cul}, \mathrm{TPPTS}, \mathrm{Et} \mathrm{N}_{3}$, $\mathrm{AN} / \mathrm{H}_{2} \mathrm{O}(1: 1), 75^{\circ} \mathrm{C}, 1 \mathrm{~h}$.

Table 1 Synthesis of nucleosides and nucleoside triphosphates bearing phenothiazine labels

\begin{tabular}{|c|c|c|c|c|c|c|}
\hline $\begin{array}{l}d^{I} \\
d^{I}\end{array}$ & \multirow[t]{2}{*}{ EPT (2) } & $\operatorname{Pd}\left(\mathrm{PPh}_{3}\right)_{2} \mathrm{Cl}_{2}, \mathrm{CuI}$ & DMF & \multirow[t]{2}{*}{$\mathrm{Et}_{3} \mathrm{~N}$} & $\begin{array}{l}\mathbf{d A} \mathbf{A}^{\mathrm{EPT}} \\
\mathbf{d C}\end{array}$ & $\begin{array}{l}93 \\
76\end{array}$ \\
\hline $\begin{array}{l}\mathbf{d A}^{\mathrm{I}} \mathbf{T P} \\
\mathbf{d C}^{\mathrm{I}} \mathbf{T P}\end{array}$ & & $\mathrm{Pd}(\mathrm{OAc})_{2}, \mathrm{CuI}, \mathrm{TPPTS}$ & $\mathrm{AN} / \mathrm{H}_{2} \mathrm{O}(1 / 1)$ & & $\begin{array}{l}\mathbf{d A}^{\mathbf{E P T}} \mathbf{T P} \\
\mathbf{d C}^{\mathrm{EPT}} \mathbf{T P}\end{array}$ & $\begin{array}{l}49 \\
48\end{array}$ \\
\hline
\end{tabular}




\section{Biochemistry}

The four new dNTPs $\left(\mathbf{d A}^{\mathbf{P T}} \mathbf{T P}, \quad \mathbf{d C}^{\mathbf{P T}} \mathbf{T P}, \quad \mathbf{d A}^{\mathbf{E P T}} \mathbf{T P}\right.$ and $\left.\mathbf{d C}^{\mathbf{E P T}} \mathbf{T P}\right)$ were then tested as substrates for DNA polymerases in primer extension experiments (PEX) using KOD XL, Vento(exo-) and Pwo polymerases (for sequences of primers, templates and products, see Table 2). The first experiment was a single nucleotide incorporation of each of the $\mathbf{d N}^{\mathbf{X}} \mathbf{T P s}$ into a 15-nt primer followed by three natural $\mathrm{dG}$ using temp ${ }^{A}$ or temp ${ }^{C}$ templates (Fig. 1). In all cases, we obtained fully extended products as shown by the analysis by polyacrylamide gel electrophoresis (PAGE). All the products were also characterized by MALDI-TOF (see Table 3). The kinetic experiments (see Fig. S1-S4 in the ESI $\dagger$ ) in the presence of KOD XL polymerase showed that the modified $\mathbf{d N}^{\mathbf{X}}$ TPs were incorporated at a slightly slower rate compared to dATP or dCTP but all of them were fully incorporated within max. 5-10 minutes. The slowest extension proceeded with $\mathbf{d} \mathbf{A}^{\mathbf{E P T}} \mathbf{T P}$.

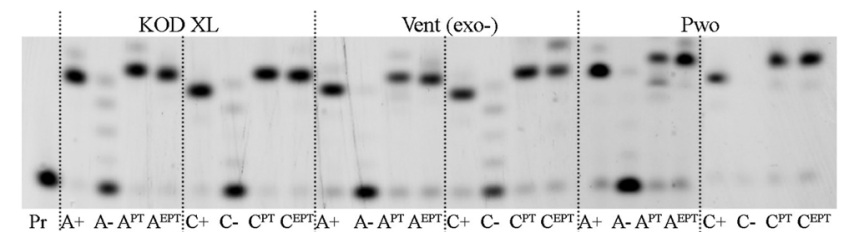

Fig. 1 Primer extension with temp ${ }^{A}$ and temp $p^{C}$ using KOD XL, Vent (exo-) and Pwo polymerases. Pr: primer; At: product of PEX with natural dNTPs; A-: product of PEX with dGTP; $\mathrm{A}^{\mathrm{PT}}$ : product of PEX with $\mathrm{dA}^{\mathrm{PT}} \mathrm{TP}$, dGTP; $A^{\text {EPT: }}$ product of PEX with $d A^{E P T} T P$, dGTP; $C+$ : product of PEX with dCTP, dGTP; $C$-: product of PEX with dGTP; $C^{\mathrm{PT}}$ : product of PEX with $\mathrm{dC}^{\mathrm{PT}} \mathrm{TP}$, dGTP; $\mathrm{C}^{\mathrm{EPT}}$ : product of PEX with $\mathrm{dC}^{\mathrm{EPT}} \mathrm{TP}$, dGTP.

Then, each of the modified $\mathbf{d N}^{\mathbf{X}}$ TPs was incorporated into a longer 31-mer oligonucleotide (ON) using temp ${ }^{\text {rnd16 }}$ designed to encode for four incorporations at each of the four nucleotides and four modifications if one of the dNTPs is modified. Furthermore, the PEX experiments gave full-length products in

Table 2 List of oligodeoxyribonucleotide sequences of templates, primers, and products ${ }^{a, b}$

\begin{tabular}{|c|c|}
\hline Name & Sequence \\
\hline Primer $^{r n d} c$ & 5'-CATGGGCGGCATGGG-3' \\
\hline Primer NICK & 5'-CCGATCTAGTGAGTCCTCG-3' \\
\hline Temp $^{\text {rnd16 }}$ & 5'-CTAGCATGAGCTCAGTCCECATGCCGGCCCATG-3' \\
\hline Nick_1A & 5'-CACTCACGACcgagGACTCACTAGATCG \\
\hline Nick_1C & 5'-CACTCATGACcgag $\overline{\mathrm{GACT}} \overline{\mathrm{CA}} \overline{\mathrm{CTA}} \overline{\mathrm{GAT}} \overline{\mathrm{C}} \overline{\mathrm{G}} \overline{\mathrm{G}}-3^{\prime}$ \\
\hline Nick_2A(2C) & 5'-CAGTCATGAAcgagGACTCACTAGATCEG $\underline{\text { - }}-3^{\prime}$ \\
\hline Nick_4A(4C) & 5'-CATGATCAGTACGTACcgagGACTCACTAGATCGG-3' \\
\hline Temp $^{A}$ & 5'-CCCTCCCAATGCCGCCCATG-3' \\
\hline Temp $^{C}$ & 5'-CCCGCCCATGC $\overline{\text { GCCCATG }}-3^{\prime}$ \\
\hline Temp $^{\text {terma }}$ & 5'-TCCCATGCCGC $\overline{\mathrm{A}} \overline{\mathrm{CATG}} \overline{\mathrm{T}} 3^{\prime}$ \\
\hline Temp $^{\text {term } C}$ & $5^{\prime}-\mathrm{G} \underline{\mathrm{C}} \underline{\mathrm{C}} \overline{\mathrm{CAT}} \underline{\mathrm{G}} \underline{\mathrm{C}} \underline{\mathrm{G}} \underline{\mathrm{C}} \underline{\mathrm{C}} \underline{\mathrm{CAT}} \underline{\mathrm{G}}-3^{\prime}$ \\
\hline $\mathrm{ON}^{\text {rnd16 }} \mathbf{A}^{\mathbf{P T}}$ & 5'-CATGGGCGGCATGGGA ${ }^{\mathbf{P T}}$ CTGA $^{\mathbf{P T}}$ GCTCA $^{\mathbf{P T}}$ TGCTA $^{\mathbf{P T}}$ G-3' \\
\hline $\mathrm{ON}^{r n d 16} \mathbf{A}^{\mathbf{E P T}}$ & 5'-CATGGGCGGCATGGG $\mathbf{A}^{\mathbf{E P T}}$ CTG $\mathbf{A}^{\mathbf{E P T}}$ GCTC $\mathbf{A}^{\mathbf{E P T}}$ TGCTA $^{\mathbf{E P T}}$ G-3' \\
\hline $\mathrm{ON}^{r n d 16} \mathbf{C}^{\mathrm{PT}}$ & 5'-CATGGGCGGCATGGGA $\mathbf{C}^{\mathbf{P T}}$ TGAGC $^{\mathbf{P T}} \mathbf{C}^{\mathbf{P T}}$ ATGC $^{\mathbf{P T}}$ TAG-3' $^{\prime}$ \\
\hline $\mathrm{ON}^{\text {rnd16 }} \mathbf{C}^{\mathbf{E P T}}$ & 5'-CATGGGCGGCATGGGA $\mathbf{C}^{\mathbf{E P T}}$ TGAGC $^{\mathbf{E P T}} \mathbf{T C}^{\mathbf{E P T}}$ ATGC $^{\mathbf{E P T}}$ TAG-3' \\
\hline $\mathrm{ON}^{r n d 16} \mathbf{A}^{\mathbf{E P T}} \mathbf{C}^{\mathbf{E B F}}$ & 5'-CATGGGCGGCATGGGA ${ }^{\mathbf{E P T}} \mathbf{C}^{\mathbf{E B F}} \mathbf{T G A}^{\mathbf{E P T}} \mathrm{GC}^{\mathbf{E B F}} \mathrm{TC}^{\mathbf{E B F}} \mathbf{A}^{\mathbf{E P T}} \mathbf{T G C}^{\mathbf{E B F}} \mathbf{T A}^{\mathbf{E P T}}$ G-3' \\
\hline $\mathrm{ON}^{\text {rnd16 }} \mathbf{A}^{\mathbf{E P T}} \mathbf{U}^{\mathbf{N O 2}}$ & 5'-CATGGGCGGCATGGGA ${ }^{\mathrm{EPT}} \mathrm{CU}^{\mathrm{NO} 2} \mathrm{GA}^{\mathrm{EPT}} \mathrm{GCU}^{\mathrm{NO} 2} \mathrm{CA}^{\mathrm{EPT}} \mathbf{U}^{\mathrm{NO} 2} \mathrm{GCU}^{\mathrm{NO} 2} \mathbf{A}^{\mathrm{EPT}} \mathrm{G}-3$ \\
\hline $\mathrm{ON}^{\mathrm{Nick} \_1 A} \mathbf{A}^{\mathbf{P T}}$ & 5'-P-GTCGTGA ${ }^{\mathbf{P T}}$ GTG-3' \\
\hline $\mathrm{ON}^{\mathrm{Nick} \_1 A} \mathbf{A}^{\mathbf{E P T}}$ & 5'-P-GTCGTGA ${ }^{\mathbf{E P T}} \mathrm{GTG}^{\prime} 3^{\prime}$ \\
\hline $\mathrm{ON}^{\mathrm{Nick} \_1 C} \mathbf{C}^{\mathrm{PT}}$ & 5'-P-GTC ${ }^{\mathrm{PT}}$ ATGAGTG -3' \\
\hline $\mathrm{ON}^{\mathrm{Nick} \_1 C} \mathbf{C}^{\mathbf{E P T}}$ & $5^{\prime}-\mathrm{P}-\mathrm{GTC}^{\mathbf{E P T}}$ ATGAGTG-3' \\
\hline $\mathrm{ON}^{\mathrm{Nick} \_2 A} \mathbf{A}^{\mathbf{P T}}$ & $5^{\prime}-\mathrm{P}-\mathrm{TTCA}^{\mathbf{P T}} \mathrm{TGA}^{\mathbf{P T}} \mathrm{CTG}-3^{\prime}$ \\
\hline $\mathrm{ON}^{\mathrm{Nick} \_2 A} \mathbf{A}^{\mathbf{E P T}}$ & $5^{\prime}-\mathrm{P}-\mathrm{TTCA}^{\mathrm{EPT}} \mathrm{TGA}^{\mathrm{EPT}} \mathrm{CTG}^{\prime} 3^{\prime}$ \\
\hline $\mathrm{ON}^{\mathrm{Nick} \_2 C} \mathbf{C}^{\mathbf{P T}}$ & $5^{\prime}-\mathrm{P}-\mathrm{TTC}^{\mathrm{PT}} \mathrm{ATGA} \mathbf{C}^{\mathrm{PT}} \mathrm{TG}^{\mathrm{T}} 3^{\prime}$ \\
\hline $\mathrm{ON}^{\mathrm{Nick} \_2 C} \mathbf{C}^{\mathbf{E P T}}$ & $5^{\prime}-\mathrm{P}-\mathrm{TTC}^{\mathrm{EPT}}$ ATGA $\mathrm{C}^{\mathrm{EPT}} \mathrm{TG}^{\prime} 3^{\prime}$ \\
\hline $\mathrm{ON}^{\mathrm{Nick} \_4 A} \mathbf{A}^{\mathrm{PT}}$ & $5^{\prime}-\mathrm{P}-\mathrm{T} \mathbf{A}^{\mathrm{PT}} \mathrm{GCA}^{\mathrm{PT}} \mathrm{TGCTA}^{\mathrm{PT}} \mathrm{CGTCA}^{\mathrm{PT}} \mathrm{G}-3^{\prime}$ \\
\hline $\mathrm{ON}^{\mathrm{Nick} \_4 A} \mathbf{A}^{\mathbf{E P T}}$ & $5^{\prime}-\mathrm{P}-\mathrm{T} \mathbf{A}^{\mathbf{E P T}} \mathrm{GCA}^{\mathbf{E P T}} \mathrm{TGCTA}^{\mathbf{E P T}} \mathrm{CGTCA}^{\mathbf{E P T}} \mathrm{G}-3^{\prime}$ \\
\hline $\mathrm{ON}^{\mathrm{Nick} \_4 A} \mathbf{C}^{\mathbf{P T}}$ & $5^{\prime}$-P-TAGC ${ }^{\mathbf{P T}}$ ATGC $^{\mathbf{P T}}$ TAC $^{\mathbf{P T}}$ GTC $^{\mathbf{P T}}$ AG-3' \\
\hline $\mathrm{ON}^{\mathrm{Nick} \_4 A} \mathbf{C}^{\mathbf{E P T}}$ & $5^{\prime}-\mathrm{P}-\mathrm{TAGC} \mathrm{CP}^{\mathrm{EPT}} \mathrm{ATGC}^{\mathrm{EPT}} \mathrm{TAC}^{\mathrm{EPT}} \mathrm{GTC}^{\mathrm{EPT}} \mathrm{AG}^{-3^{\prime}}$ \\
\hline $\mathrm{ON}^{A} \mathbf{A}^{\mathbf{P T}}$ & 5'-CATGGGCGGCATGGGA ${ }^{\mathbf{P T}}$ GGG-3' \\
\hline $\mathrm{ON}^{A} \mathbf{A}^{\mathbf{E P T}}$ & 5'-CATGGGCGGCATGGGA ${ }^{\mathbf{E P T}}$ GGG-3' \\
\hline $\mathrm{ON}^{C} \mathbf{C}^{\mathbf{P T}}$ & 5'-CATGGGCGGCATGGGC ${ }^{\mathbf{P T}}$ GGG-3' \\
\hline $\mathrm{ON}^{C} \mathbf{C}^{\mathbf{E P T}}$ & 5'-CATGGGCGGCATGGGC ${ }^{\mathbf{E P T}}$ GGG-3' $^{\prime}$ \\
\hline $\mathrm{ON}^{\text {terma }} \mathbf{A}^{\mathbf{P T}}$ & 5'-CATGGGCGGCATGGGA ${ }^{\mathbf{P T}}-3^{\prime}$ \\
\hline $\mathrm{ON}^{\text {termA }} \mathbf{A}^{\mathbf{E P T}}$ & $5^{\prime}$-CATGGGCGGCATGGGA ${ }^{\mathbf{E P T}}-3^{\prime}$ \\
\hline $\mathrm{ON}^{\text {termC }} \mathbf{C}^{\mathbf{P T}}$ & $5^{\prime}$-CATGGGCGGCATGGGC ${ }^{\mathbf{P T}}-3^{\prime}$ \\
\hline $\mathrm{ON}^{\text {termC }} \mathbf{C}^{\mathbf{E P T}}$ & $5^{\prime}$-CATGGGCGGCATGGGC ${ }^{\mathbf{E P T}}-3^{\prime}$ \\
\hline
\end{tabular}

${ }^{a}$ For magnetoseparation of the extended primer strands, the templates were $5^{\prime}$ - end biotinylated. ${ }^{b}$ Primer sequences in the template are underlined. ${ }^{c}$ 6-Carboxyfluorescein- (6-FAM-) labeled primer ${ }^{r n d}$ was used for visualization in PEX experiments and TDT elongation. 
Table 3 List of MALDI data of PT-labelled ONs prepared by PEX followed by magnetoseparation

\begin{tabular}{|c|c|c|}
\hline Oligonucleotide & $M$ calcd (Da) & $M$ found (Da) \\
\hline $\mathrm{ON}^{r n d 16} \mathbf{A}^{\mathbf{P T}}$ & 10458.5 & 10459.0 \\
\hline $\mathrm{ON}^{r n d 16} \mathbf{A}^{\mathbf{E P T}}$ & 10554.5 & 10555.3 \\
\hline $\mathrm{ON}^{\text {rnd16 }} \mathbf{C}^{\mathbf{P T}}$ & 10462.5 & 10463.8 \\
\hline $\mathrm{ON}^{r n d 16} \mathbf{C}^{\mathbf{E P T}}$ & 10558.5 & 10559.3 \\
\hline $\mathrm{ON}^{r n d 16} \mathbf{A}^{\mathbf{E P T}} \mathbf{C}^{\mathbf{E B F}}$ & 11031.1 & 11032.9 \\
\hline $\mathrm{ON}^{r n d 16} \mathbf{A}^{\mathbf{E P T}} \mathbf{T}^{\mathbf{N O} 2}$ & 10886.9 & 10887.3 \\
\hline $\mathrm{ON}^{\mathrm{Nick} \_1 A} \mathbf{A}^{\mathbf{P T}}$ & 3388.3 & 3389.4 \\
\hline $\mathrm{ON}^{\text {Nick_1A }} \mathbf{A}^{\mathbf{E P T}}$ & 3412.3 & 3413.4 \\
\hline $\mathrm{ON}^{\text {Nick_1C }} \mathbf{C}^{\mathbf{P T}}$ & 3373.7 & 3374.5 \\
\hline $\mathrm{ON}^{\text {Nick } \_1 C} \mathbf{C}^{\mathbf{E}} \mathbf{P T}$ & 3397.4 & 3398.4 \\
\hline $\mathrm{ON}^{\mathrm{Nick} \_2 A} \mathbf{A}^{\mathbf{P T}}$ & 3517.6 & 3519.3 \\
\hline $\mathrm{ON}^{\text {Nick_2A }} \mathbf{A}^{\mathbf{E P T}}$ & 3565.6 & 3566.8 \\
\hline $\mathrm{ON}^{\mathrm{Nick} \_2 C} \mathbf{C}^{\mathbf{P T}}$ & 3519.6 & 3520.4 \\
\hline $\mathrm{ON}^{\mathrm{Nick} \_2 C} \mathbf{C}^{\mathbf{E P T}}$ & 3567.6 & 3568.7 \\
\hline $\mathrm{ON}^{\text {Nick_4A }} \mathbf{A}^{\mathbf{P T}}$ & 5801.4 & 5802.8 \\
\hline $\mathrm{ON}^{\mathrm{Nick} \_4 A} \mathbf{A}^{\mathbf{E P T}}$ & 5897.4 & 5898.7 \\
\hline $\mathrm{ON}^{\text {Nick_} \_4 C} \mathbf{C}^{\mathbf{P T}}$ & 5805.4 & 5806.6 \\
\hline $\mathrm{ON}^{\text {Nick_} \_4 C} \mathbf{C}^{\mathbf{E P T}}$ & 5901.4 & 5902.5 \\
\hline $\mathrm{ON}^{A} \mathbf{A}^{\mathbf{P T}}$ & 6185.2 & 6186.5 \\
\hline $\mathrm{ON}^{A} \mathbf{A}^{\mathbf{E P T Z}}$ & 6209.2 & 6210.6 \\
\hline $\mathrm{ON}^{C} \mathbf{C}^{\mathbf{P T}}$ & 6162.2 & 6163.5 \\
\hline $\mathrm{ON}^{C} \mathbf{C}^{\mathbf{E P T}}$ & 6186.2 & 6187.5 \\
\hline
\end{tabular}

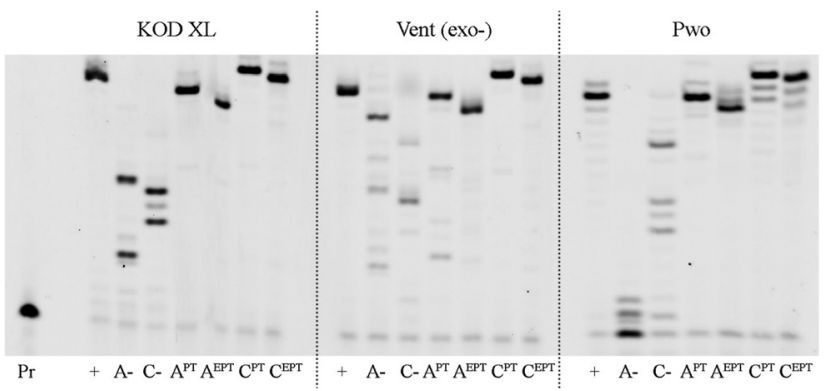

Fig. 2 Primer extension with temp ${ }^{\text {rnd16 }}$ using KOD XL, Vent(exo-) and Pwo polymerases. Pr: primer; +: product of PEX with natural dNTPs; A-: product of PEX with dCTP, dTTP, dGTP; C-: product of PEX with dATP,

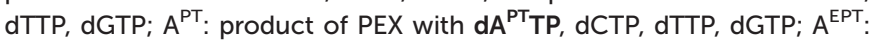
product of PEX with $d A^{E P T} T P, d C T P, d T T P$, dGTP; $C^{P T}$ : product of PEX with $\mathrm{dC}^{\mathrm{PT}} \mathrm{TP}, \mathrm{dATP}$, dTTP, dGTP; $\mathrm{C}^{\mathrm{EPT}}$ : product of PEX with $\mathrm{dC}^{\mathrm{EPT}} \mathrm{TP}$, dATP, dTTP, dGTP.

the presence of all tested polymerases (Fig. 2). The PEX products have slightly different electrophoretic mobility but their correct length and sequence was verified by MALDI (Table 3).

In order to test the possibility of use of the PT-labelled nucleotides for redox coding of DNA bases, we synthesized ON containing redox-labelled $\mathrm{A}$ and in combination with redoxlabelled $\mathrm{C}$ or $\mathrm{T}\left(\mathbf{A}^{\mathrm{PT}}+\mathbf{C}^{\mathrm{EBF}}\right.$ or $\left.\mathbf{A}^{\mathrm{MOP}}+\mathbf{U}^{\mathrm{NO} 2}\right)$. The PEX experiments combining the use of $\mathbf{d} \mathbf{A}^{\mathbf{P T}} \mathbf{T P}$ with previously reported $\mathbf{d C}^{\mathrm{EBF}} \mathbf{T P}^{9}$ or $\mathbf{d U}^{\mathrm{NO2}} \mathbf{T P}^{5}$ were also successful to give full-length ONs bearing four $\mathbf{A}^{\mathbf{P T}}$ labels in combination with either four $\mathbf{C}^{\mathrm{EBF}}$ or four $\mathbf{U}^{\mathrm{NO} 2}$ modifications (Fig. 3 and 4). These ON products were also characterized by MALDI (Table 3 ).

We also tried the use of the $\mathbf{d N}^{\mathrm{XPT}} \mathbf{T P s}$ in PCR amplifications, but the PCR reactions using KOD XL did not give a significant product (see Fig. S6 in ESI $\dagger$ ). Since the $\mathbf{d N}^{\mathbf{X P T}} \mathbf{T P s}$ are

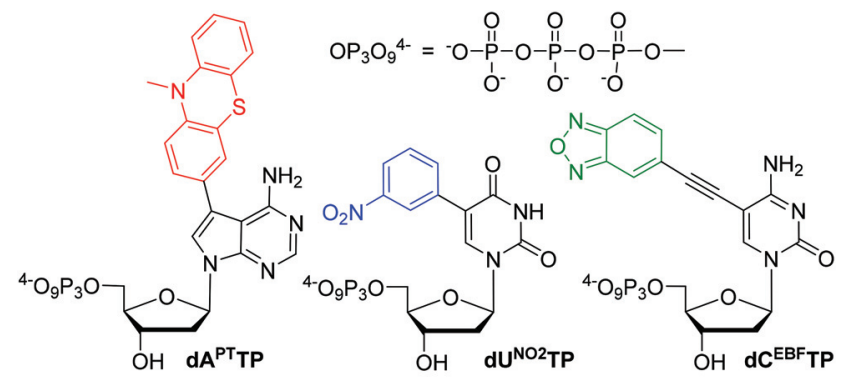

PEX: dA ${ }^{\mathrm{PT} T P}, \mathrm{dU}^{\mathrm{NO}}{ }^{\mathrm{T}} \mathrm{TP}, \mathrm{dCTP}, \mathrm{dGTP} \quad$ PEX: $d A^{\mathrm{PT}}$ TP, dC ${ }^{\mathrm{EBF}}$ TP, dTTP, dGTP

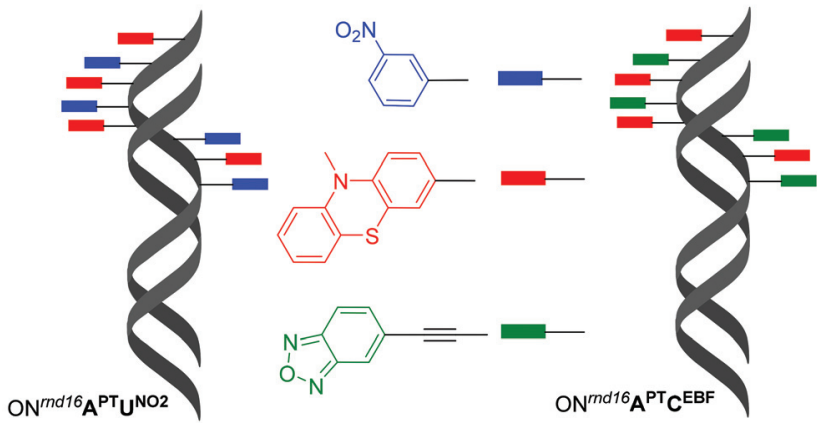

Fig. 3 Redox coding of DNA bases: structures of redox-labelled dNTPs and DNA products of the mixed PEX.

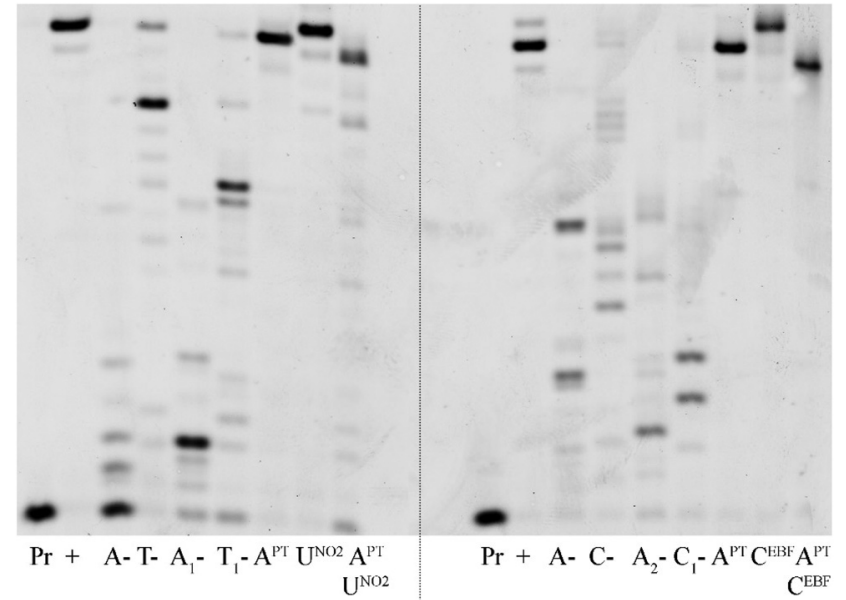

Fig. 4 Primer extension with temp $p^{\text {rnd16 }}$ using KOD XL polymerase and combinations of redox-labelled dNTPs. Pr: primer; +: product of PEX with natural dNTPs; A-: product of PEX with dCTP, dTTP, dGTP; T-: product of PEX with dATP, dCTP, dGTP; $A_{1}-$ : product of PEX with $\mathrm{dT}^{\mathrm{NO}} \mathrm{TP}, \mathrm{dCTP}$, dGTP; $\mathrm{T}_{1}$-: product of PEX with $\mathrm{dA}^{\mathrm{PT}} \mathrm{TP}, \mathrm{dCTP}, \mathrm{dGTP}$; $A^{\mathrm{PT}}$ : product of $\mathrm{PEX}$ with $d A^{\mathrm{PT}} \mathrm{TP}, \mathrm{dCTP}, \mathrm{dTTP}, \mathrm{dGTP}$; $\mathrm{U}^{\mathrm{NO} 2}$ : product of $P E X$ with $d^{N O 2} T P, d A T P, d C T P, d G T P ; A^{P T} U^{N O 2}$ : product of PEX with $\mathrm{dA}^{\mathrm{PT}} \mathrm{TP}, \mathrm{dU}^{\mathrm{NO}} \mathrm{TP}, \mathrm{dCTP}$, dGTP; C-: product of PEX with dATP, dTTP, dGTP; $A_{2}-$ : product of PEX with $\mathrm{dC}^{\mathrm{EBF}} \mathrm{TP}, \mathrm{dTTP}, \mathrm{dGTP}, \mathrm{C}_{1}{ }^{-}$: product of PEX with $d A^{P T} T P, d T T P, d G T P ; C^{E B F}$ : product of PEX with $d^{E B F} T P, d A T P$, dTTP, dGTP; $A^{\mathrm{PT}} C^{\mathrm{EBF}}$ : product of PEX with $\mathrm{dA}{ }^{\mathrm{PT}} \mathrm{TP}, \mathrm{dC} \mathrm{C}^{\mathrm{EBF}} \mathrm{TP}, \mathrm{dTTP}$, dGTP.

reasonably good substrates for these polymerases in the PEX experiments, the problem is probably in the limited ability of the enzymes to read through the PT-modified templates. We also tested PCR reactions with mixtures of natural dATP and 


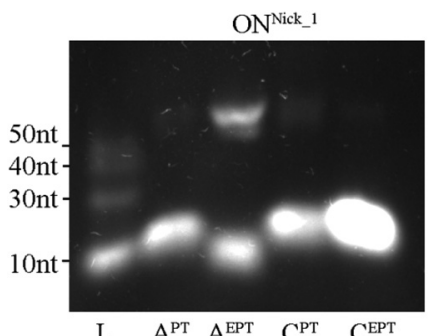

$\begin{array}{lllll}\mathrm{L} & \mathrm{A}^{\mathrm{PT}} & \mathrm{A}^{\mathrm{EPT}} & \mathrm{C}^{\mathrm{PT}} & \mathrm{C}^{\mathrm{EPT}}\end{array}$

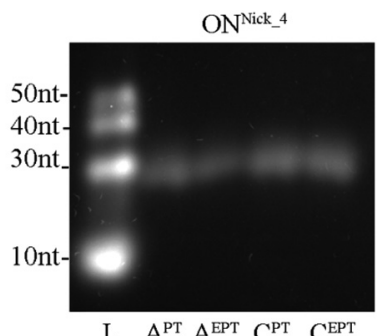

L $\quad \mathrm{A}^{\mathrm{PT}} \mathrm{A}^{\mathrm{EPT}} \mathrm{C}^{\mathrm{PT}} \mathrm{C}^{\mathrm{EPT}}$

Fig. 5 Incorporation of modified dNTPs in NEAR using Nick_1A, Nick_1C and Nick_4A(4C) templates. L: DNA ladder; $A^{\mathrm{PT}}$ : product of NEAR with $d A^{P T} T P, d C T P$, dGTP, dTTP; $A^{E P T}$ : product of NEAR with $d A^{\text {EPT TP, }}$ dCTP, dGTP, dTTP, $C^{\text {PT }}$ : product of NEAR with $\mathrm{dC}^{\mathrm{PT}} \mathrm{TP}, \mathrm{dATP}$, dGTP, dTTP, C ${ }^{\text {EPT }}$ : product of NEAR with dC EPTTP, dATP, dGTP, dTTP.

modified $\mathbf{d} \mathbf{A}^{\mathbf{P T}} \mathbf{T P}$ or $\mathbf{d A}^{\mathbf{E P T}} \mathbf{T P}$, and only the experiment with $50 \%$ of $\mathbf{d A}^{\mathbf{P T}} \mathbf{T P}$ in the presence of natural dATP gave a significant product of amplification (see Fig. S7 and S8 $\dagger$ ).

Next, we tested whether the new $\mathbf{d} \mathbf{N}^{\mathbf{X P T}} \mathbf{T P s}$ could be used in the nicking enzyme amplification reaction (NEAR), which is used for enzymatic synthesis of short single-stranded ONs. ${ }^{32}$ The principle of the method is that a PEX reaction is performed in the presence of Vent (exo-) polymerase and a nicking endonuclease (in our case Nt.BstNBI), which cleaves the extended strand to release the modified $\mathrm{ssON} .{ }^{33}$ We tested the NEAR amplification using three different templates designed for the synthesis of ON containing either one, two or four modifications (10-mer ON containing either one or two modifications or 16-mer ON containing four modifications). Fig. 5 (and Fig. S5 in the ESI†) shows the outcome of these experiments. The ssONs containing one modification were obtained efficiently in case of each of the four $\mathbf{d N}^{\mathbf{X P T}} \mathbf{T P S}$, whereas the products containing two or four labels were still obtained (though in lower yield).

The last enzymatic method tested in this work was the nontemplated 3 '-tail labelling by terminal deoxynucleotidyl transferase (TdT). ${ }^{34,35}$ Fig. 6 shows that the TdT-catalyzed elongation of the primer using $\mathbf{d A}^{\mathbf{P T}} \mathbf{T P}$ gave almost the perfect

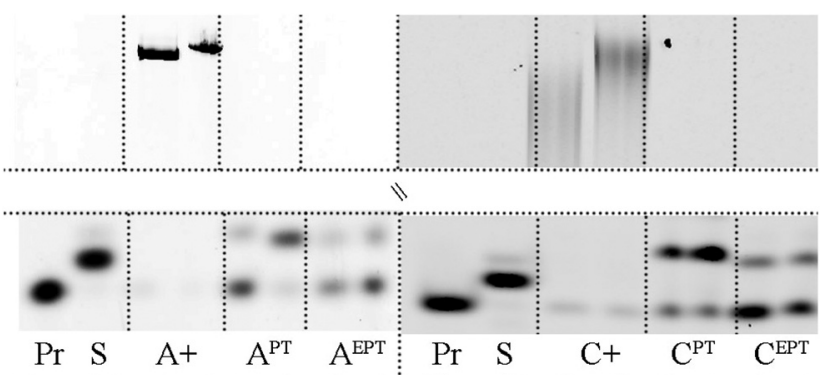

Time (h): $1 \begin{array}{llllll:llllllll} & 4 & 1 & 4 & 1 & 4 & \text { Time (h): } & 1 & 4 & 1 & 4 & 1 & 4\end{array}$

Fig. 6 TdT-catalyzed DNA chain elongation. Pr: primer $^{\text {rnd }}$; S: standard (PEX product of temp ${ }^{\text {termA }}$ with dATP or temp ${ }^{\text {term } C}$ with dCTP); $A+, A^{\text {PT }}$ and $A^{E P T}$ : products of primer ${ }^{\text {rnd }}$ elongation using terminal transferase and either $\mathrm{dATP}, \mathrm{dA} \mathrm{A}^{\mathrm{PT} T P}$ or $\mathrm{dA}^{\mathrm{EPT}} \mathrm{TP}$ respectively; $\mathrm{C}+, \mathrm{C}^{\mathrm{PT}}$ and $\mathrm{C}^{\mathrm{EPT}}$ : products of primer ${ }^{\text {rnd }}$ elongation using terminal transferase and either dCTP, dC ${ }^{\mathrm{PT}} \mathrm{TP}$ or $\mathrm{dC}^{\mathrm{EPT}}$ TP respectively (for the full gel image, see Fig. $\mathrm{S} 9$ and $\mathrm{S} 10 \dagger$ ).

Table 4 Spectroscopic properties of all new fluorescent compounds

\begin{tabular}{llllll}
\hline Compound & Solvent $\begin{array}{c}\lambda_{\text {abs }}{ }^{a} \\
{[\mathrm{~nm}]}\end{array}$ & $\begin{array}{l}\varepsilon \\
{\left[10^{3} \mathrm{M}^{-1} \mathrm{~cm}^{-1}\right]^{b}}\end{array}$ & $\begin{array}{l}\lambda_{\mathrm{em}}{ }^{c} \\
{[\mathrm{~nm}]}\end{array}$ & $\Phi_{\mathrm{f}}{ }^{d}$ \\
\hline $\mathbf{d A}^{\mathrm{EPT}}$ & EtOH & 344 & 16.4 & 462 & $0.1889 \pm 0.0116$ \\
& & 296 & 32.8 & & \\
& & 267 & 35.9 & & \\
$\mathbf{d C}^{\mathrm{EPT}}$ & $\mathrm{EtOH}$ & 346 & 6.2 & 476 & $0.0101 \pm 0.0004$ \\
& & 277 & 14.4 & & \\
$\mathbf{d A}^{\mathrm{EPT}} \mathbf{T P}$ & $\mathrm{H}_{2} \mathrm{O}$ & 336 & 11.4 & 486 & $0.014 \pm 0.0003$ \\
$\mathbf{d C}^{\mathrm{EPT}} \mathbf{T P}$ & & 270 & 24.9 & & \\
& $\mathrm{H}_{2} \mathrm{O}$ & 340 & 8.4 & 489 & $0.0014 \pm 0.0001$ \\
& & 275 & 19.8 & &
\end{tabular}

${ }^{a}$ Position of the absorption maximum, $\pm 1 \mathrm{~nm} .{ }^{b}$ Confidence interval did not exceed $\pm 0.2 \times 10^{3} \mathrm{M}^{-1} \mathrm{~cm}^{-1}$. ${ }^{c}$ Position of the emission maximum, $\pm 1 \mathrm{~nm} .{ }^{d}$ Quantum yield of fluorescence measured using quinine sulfate in $0.5 \mathrm{M} \mathrm{H}_{2} \mathrm{SO}_{4}\left(\Phi_{\mathrm{f}}=0.546\right.$ at $\left.25^{\circ} \mathrm{C}\right)$ as a standard.

product of single nucleotide extension, whereas the other $\mathbf{d N}^{\mathbf{X P T}}$ TPs were less efficient. The single nucleotide extension can advantageously be used for specific incorporation of one PT-redox label at the $3^{\prime}$-end of ON analytes.

\section{Fluorescence}

In order to verify the possible applications in fluorescence labelling of DNA, we measured the absorption and emission spectra of PT-modified nucleosides and triphosphates. Table 4 shows that the nucleosides in ethanol showed significant fluorescence with emission maxima at $462-476 \mathrm{~nm}$, whereas the fluorescence of $\mathbf{d N}^{\mathrm{XPT}} \mathbf{T P s}$ in water was negligible. The fluorescence of the PEX product $\mathrm{ON}^{\text {rnd16 }} \mathbf{A}^{\mathbf{E P T}}$ containing four $\mathbf{A}^{\mathbf{E P T}}$ modifications was moderate (see Fig. S13 in ESI $\dagger$ ).

\section{Electrochemistry}

Electrochemical properties of PT- and EPT-deoxynucleoside conjugates ( $\mathbf{d N}^{\mathbf{P T}}$ or $\mathbf{d} \mathbf{N}^{\mathrm{EPT}}$, respectively) and of PT-modified oligonucleotides were studied by means of cyclic (CV) and square-wave (SWV) voltammetry at the basal-plane pyrolytic graphite electrode (PGE). First, we compared electrochemical oxidation of free PT with individual modified nucleosides (Fig. 7, 8, S36 and S37†). PT alone yielded two oxidation signals in the potential range between +0.5 and +1.0 V. According to the literature, ${ }^{15}$ the first signal (denominated here as peak $\mathrm{PT}^{\mathrm{ox} 1}$, around $+0.6 \mathrm{~V}$, Fig. 7a) corresponds to oneelectron reversible oxidation to form a radical cation at the PT nitrogen atom. The second one-electron oxidation step (reflected in peak $\mathrm{PT}^{\text {ox } 2}$ around $+0.9 \mathrm{~V}$ ) is irreversible and results in the formation of the corresponding sulfoxide. Cyclic voltammograms of PT (Fig. 7a) accorded with the above mechanism: when the anodic CV scan was turned back at $+0.8 \mathrm{~V}$, i.e., without applying potentials sufficiently positive for the sulfoxide formation, a cathodic counter peak to the peak $\mathrm{PT}^{\mathrm{ox} 1}$ was observed, giving evidence about the reversibility of the first oxidation step. On the other hand, when the CV scan was turned "after" the peak $\mathrm{PT}^{\mathrm{ox} 2}$, the cathodic signal disappeared in agreement with the overall irreversibility of the two-step PT oxidation. Another irreversible anodic signal was observed 


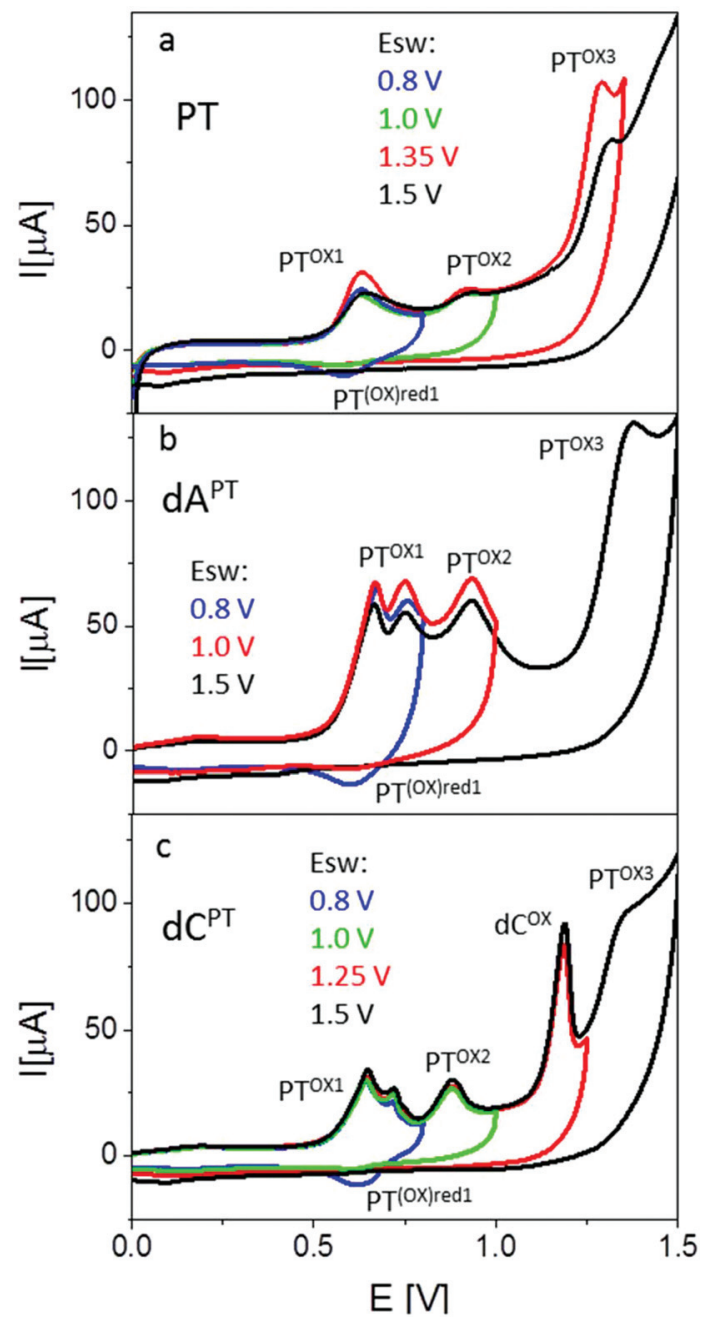

Fig. $7 \mathrm{CV}$ responses of phenothiazine (a), $d A^{\mathrm{PT}}(\mathrm{b})$, and $d C^{\mathrm{PT}}$ (c) at PGE. $C=40 \mu \mathrm{M}$, background electrolyte $0.2 \mathrm{M}$ acetate buffer ( $\mathrm{pH}$ 5.0). CV parameters: scan rate $1 \mathrm{~V} \mathrm{~s}^{-1}, E_{\mathrm{i}}=0.0 \mathrm{~V}, E_{\mathrm{sw}}$ see legend in the figure.

around $+1.3 \mathrm{~V}$, suggesting further oxidation of the PT sulfoxide (Fig. 7a). Results of SWV measurements (Fig. 8), including inspection of the forward and backward components of the SWV current to evidence the (ir)reversibility of the processes (see Fig. S37 $\dagger$ ), accorded with CV data.

Basically, CVs and SWVs of $\mathbf{d A} \mathbf{A}^{\mathbf{P T}}$ and $\mathbf{d C ^ { \mathrm { TT } }}$ displayed signals characteristic for the PT moiety (Fig. $7 \mathrm{~b}$ and c, S36 case of the conjugates only the peak $\mathrm{PT}^{\mathrm{ox} 1}$ was apparently split into two distinct signals. The reversibility of PT oxidation was retained when the $\mathrm{CV}$ scan was turned after the more positive one of them (at $+0.80 \mathrm{~V}$ ), but lost when the scan was turned at $+1.0 \mathrm{~V}$. The signals around $+0.85-+0.90 \mathrm{~V}$ were thus identified as the peak $\mathrm{PT}^{\mathrm{Ox} 2}$ corresponding to the second irreversible oxidation step. In addition to the PT-specific signals, the $\mathbf{d C}^{\mathbf{P T}}$ conjugate yielded a well-developed, irreversible peak close to $+1.2 \mathrm{~V}$. An analogous peak was produced by $\mathbf{d C}^{\mathrm{EPT}}$ but not by either of the $\mathbf{d A}^{\mathbf{P T}}$ or $\mathbf{d A}^{\mathbf{E P T}}$ conjugates (see CVs in Fig. S36† and SWVs in Fig. 8), suggesting involvement of the cytosine moiety in the corresponding electrode process. The absence of

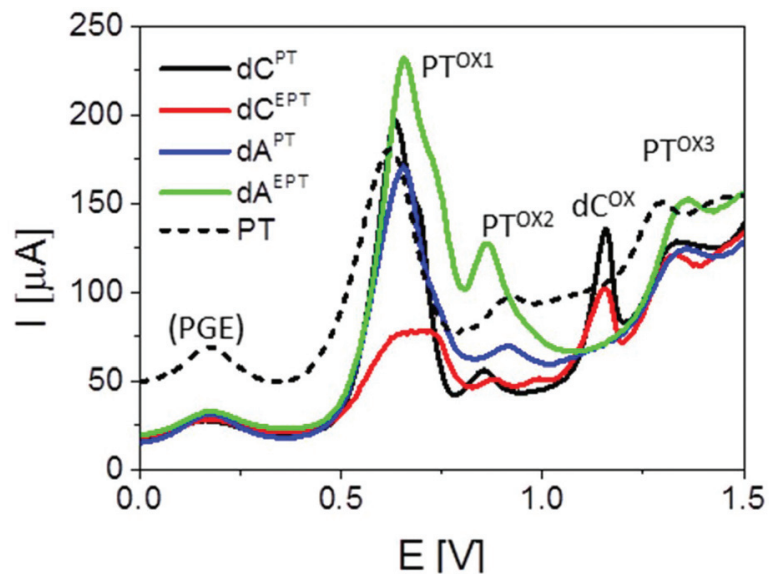

Fig. 8 Comparison of SWV responses of PTZ and PT- or EPT-modified nucleosides. SWV parameters: frequency $200 \mathrm{~Hz}$, amplitude $50 \mathrm{mV}, E_{\mathrm{i}}=$ $0.0 \mathrm{~V}$. Peak denoted as (PGE) is produced by the electrode due to the presence of oxygenous functional groups at its surface. For other details, see Fig. 7.

a base-specific signal on the voltammograms of $\mathbf{d A} \mathbf{A}^{\mathbf{P T}}$ or $\mathbf{d A} \mathbf{A}^{\mathbf{E P T}}$ may be rather surprising as 7-deazaadenine was reported to undergo irreversible electrochemical oxidation at the PGE both in its underivatized form (around $+1.1 \mathrm{~V}$ ) ${ }^{36}$ and in conjugates with, e.g., trisbipyridine complexes of Os or Ru (between +0.9 and $+1.0 \mathrm{~V}) .{ }^{6}$ An explanation of the absence of a distinct 7-deazaA peak on voltammograms of its PT conjugates may lie in its overlap with a PT signal, possibly peak $\mathrm{PT}^{\text {ox }}$. A more extensive electrochemical study, which is out of the scope of this report, will be required to understand the electrooxidation processes of (E)PT and nucleobase moieties in the $\mathbf{d N}^{\mathrm{PT}}$ conjugates in more detail.

In the next experiments, we used SWV to measure the electrochemical responses of ONs with incorporated PT- or EPT-labelled nucleotides. In the first series, we analyzed short 10- or 16-mer ON-products of NEAR bearing 1, 2 or $4 \mathbf{d A}^{\mathbf{P T}}$ conjugates (for sequences of templates see Table 2). Control unmodified NEAR products (blue curves in Fig. 9a and b, shown for $\mathrm{ON}^{\text {Nick_1C }}$ ) yielded well-developed signals of the oxidation of natural purine bases (peaks $\mathrm{G}^{\mathrm{ox}}$ and $\mathrm{A}^{\mathrm{ox}}$ ), the intensities of which reflected relative contents of $\mathrm{G}$ and $\mathrm{A}$ in the given ON (see sequences in Table 2). For the $\mathbf{d A}^{\mathbf{P T}}$-modified ONs, peaks corresponding to individual oxidation steps of PT were observed; even for the $\mathrm{ON}^{\text {nick_1A }}{ }^{\mathrm{PT}}$ bearing a single PT moiety, small but distinct peaks $\mathrm{PT}^{\mathrm{ox} 1}, \mathrm{PT}^{\mathrm{Ox} 2}$ and $\mathrm{PT}^{\mathrm{ox} 3}$ were detected. Their potentials were in general shifted to less positive values, as compared to the corresponding peak potentials measured with the nucleosides (see Table S1 $\dagger$ ). The first two peaks occurred at potentials sufficiently less positive than the potentials of the purine oxidation signals, making it possible to measure them independently, while peak $\mathrm{PT}^{\mathrm{ox} 3}$ was overlapping with peak $\mathrm{A}^{\text {ox }}$ and its observation was possible only owing to the fact that the $\mathbf{d} \mathbf{A}^{\mathbf{P T}}$-modified NEAR products did not contain any natural adenine residues (unlike the PEX products that always contained adenines, see Fig. 10). Following the 


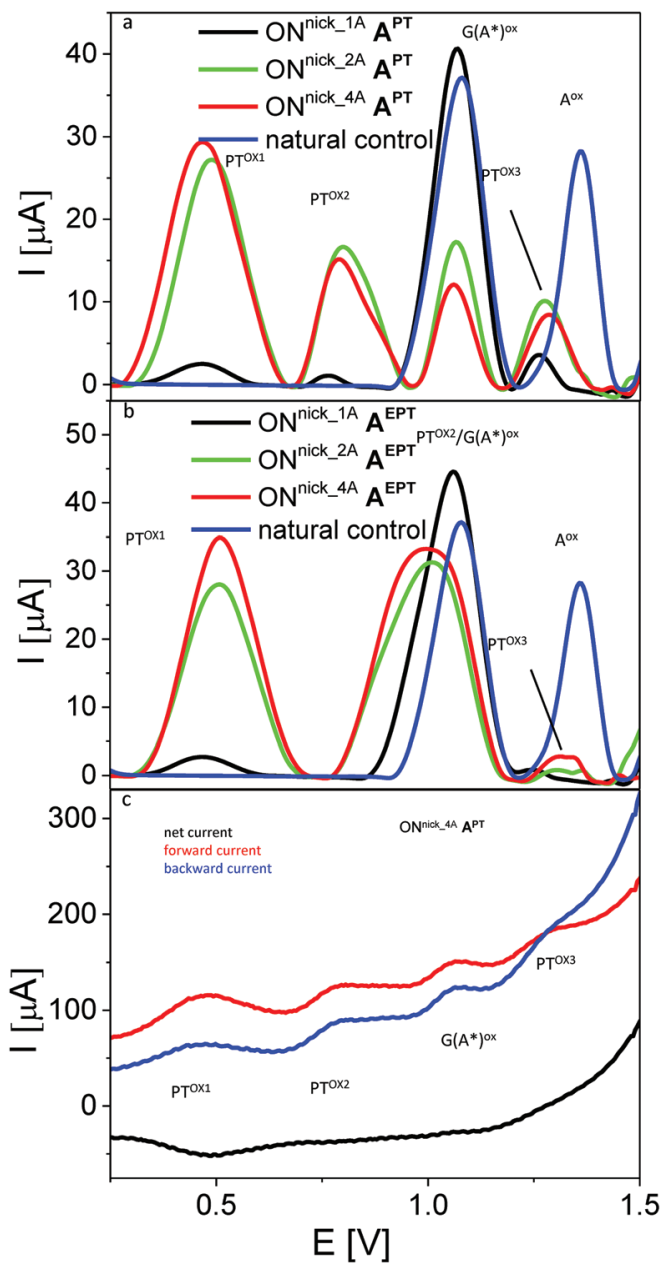

Fig. 9 (a, b) Sections of baseline-corrected AdTS SWV responses of NEAR products involving different number of PT-modified nucleobases. (c) Components of the SWV current for sample $\mathrm{ON}^{\text {nick_}}{ }^{4 A} A^{P T}$. In all panels, $t_{\mathrm{a}}=1 \mathrm{~min}$; for other details see Fig. 7 and 8 .

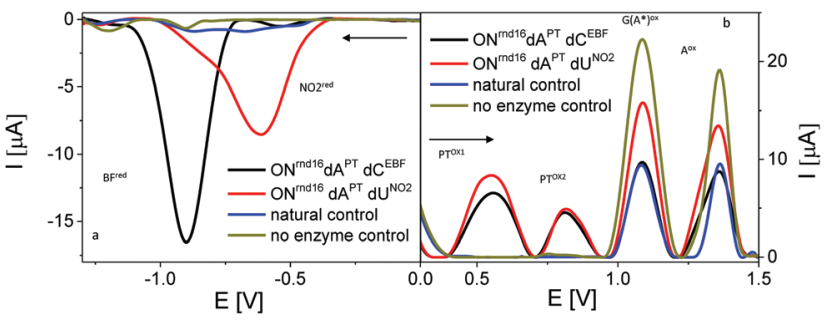

Fig. 10 Sections of baseline-corrected AdTS SWV responses of PEX products bearing $\mathrm{PT}$ labels combined with $\mathrm{EBF}$ or $\mathrm{PhNO}_{2}$ labels. (a) Cathodic reduction of $\mathrm{BF}$ and $\mathrm{NO}_{2}$ and (b) anodic oxidation of PT and nucleobase moieties. In both cases $E_{\mathrm{i}}$ was set at $0.0 \mathrm{~V}$; arrows indicate scan direction; for other details see Fig. 7 and 8.

intensities of the measured signals in dependence on the number of PT moieties incorporated, one can see a significantly non-linear behavior, with a large difference between NEAR products containing 1 and 2 PT labels (black and green curve in Fig. 9a) and very similar peak heights obtained for 2 and 4 PT moieties (green and red curve in Fig. 9a). Nevertheless, it should be noted that the latter ON $^{\text {nick } \_4 \mathrm{~A}} \mathbf{A}^{\mathbf{P T}}$ was 16-mer (while $\mathrm{ON}^{\text {nick__A }} \mathbf{A}^{\mathbf{P T}}$ and $\mathrm{ON}^{\text {nick_2A }}{ }^{\mathbf{P T}} \mathbf{A}^{\mathbf{P T}}$ were 10 -mers), and thus the relative content of PT in the 16-mer was higher only by a factor of 1.25 (instead of 2), compared to $\mathrm{ON}^{\text {nick } \_2 \mathrm{~A}} \mathrm{~A}^{\mathrm{PT}}$. Thus, the small difference between 4 and 2 PT moieties can be ascribed primarily to this fact. On the other hand, the difference between the decanucleotides may be due to a strong effect of the PT moieties on interactions of the ON with the PGE surface, such as preferential adsorption of the PT tags.

A different behavior was observed with analogous NEAR products labelled with $\mathbf{d A}^{\mathbf{E P T}}$ (Fig. 9b). While the peak PT ${ }^{\text {ox1 }}$ produced by these modified ONs was similar to that in the case of ONs bearing $\mathbf{d A} \mathbf{A}^{\mathbf{P T}}$, well separated from other signals and exhibiting similar changes in peak heights depending on the number of EPT conjugates incorporated, peak $\mathrm{PT}^{\mathrm{ox} 2}$ was shifted to a more positive potential, making it overlap with peak $\mathrm{G}^{\mathrm{ox}}$. As a consequence, it was not possible to differentiate between these two signals and measure their intensities. Again, involvement of the ethynyl linker in the electrooxidation processes of EPT-modified DNA is a matter of specialized study and will be published elsewhere. Inspection of the SWV current components (Fig. 9c) confirmed the reversibility of the electrode process giving rise to the peak $\mathrm{PT}^{\mathrm{ox} 1}$ for the (E)PT moiety incorporated into DNA, and the irreversibility of the more negative signals produced by either the PT or the nucleobases. Based on the above observations, for the next experiments we chose the $\mathbf{d} \mathbf{A}^{\mathbf{P T}}$ conjugates producing distinct PTspecific and natural base-specific signals without mutual overlaps.

To test applicability of PT as a label in a "multicolor" redox coding system, we prepared PEX products modified with $\mathbf{d A}^{\mathbf{P T}}$ combined with either of the following reducible labels, ethynyl benzofurazane (as $\mathbf{d C}^{\mathbf{E B F}}$ ) and nitrophenyl (as $\mathbf{d U}^{\mathrm{NO2}}$ ). Again, the PT labels yielded characteristic oxidation peaks $\mathrm{PT}^{\mathrm{ox} 1}$ and $\mathrm{PT}^{\mathrm{Ox} 2}$ on SWVs measured in the anodic direction, where the purine-specific peaks were also detected (Fig. 10). EBF and $\mathrm{PhNO}_{2}$ yielded, in agreement with previous literature, specific reduction signals around $-0.95 \mathrm{~V}$ and $-0.55 \mathrm{~V}$, respectively. When the measurements were performed with ONs freshly adsorbed at the electrode and the initial potential $\left(E_{\mathrm{i}}\right)$ was set at $0.0 \mathrm{~V}$, no interfering anodic signals of ONs modified with $\mathrm{BF}$ or $\mathrm{PhNO}_{2}$ were detected in the anodic scan. Similarly, no interfering reduction peak originating from PT labels was observed in the cathodic scans starting from $0.0 \mathrm{~V}$ (Fig. 10). Therefore, all three labels could easily be differentiated and determined independently by their peak potentials and/or by the direction of electron flow.

\section{Conclusions}

We developed the synthesis of 2'-deoxycytidine and 2'-deoxy-7deazaadenosine nucleosides and dNTPs bearing phenothiazine linked directly or through an acetylene tether at position 5 of cytosine or at position 7 of 7 -deazaadenine. The $\mathbf{d N}^{\mathbf{X P T}} \mathbf{T P s}$ 
were good substrates for DNA polymerases and served as building blocks for enzymatic synthesis of modified ON and DNA through PEX and NEAR (but did not work well in PCR amplification). Interestingly, $\mathbf{d} \mathbf{A}^{\mathbf{P T}} \mathbf{T P}$ and $\mathbf{d C}^{\mathbf{P T}} \mathbf{T P}$ gave efficient and selective non-templated single-nucleotide extension catalyzed by TdT. The nucleosides showed interesting fluorescence in EtOH but the nucleotides and EPT-modified DNA showed low fluorescence in water. The phenothiazine moiety is a useful redox label for nucleosides and DNA, giving two anodic peaks of PT oxidation, which are analytically useful. The directly linked $\mathbf{A}^{\mathbf{P T}}$ is more useful than the ethynyl-linked $\mathbf{A}^{\mathbf{E P T}}$ base where the second oxidation peak overlaps with oxidation of guanine. The PT-redox label is orthogonal to previously reported benzofurazane ${ }^{9}$ and nitrophenyl labels ${ }^{5}$ and can be used for multipotential redox coding of DNA bases. ${ }^{12}$ The characteristic reversibility of the first PT signal and the irreversibility of the two-step oxidation process can be exploited for unambiguous identification of the PT label among other oxidizable moieties. Thus, although the presence of two oxidation peaks apparently limits the potential space for a combination of more oxidizable DNA labels, using proper measuring parameters can help one to attain satisfactory selectivity even in the case of overlapping primary oxidation signals. On the other hand, further studies of other alternative oxidizable labels are still needed to introduce the last (fourth) redox label in prospective four-label coding.

\section{Experimental}

Chemicals, synthetic oligodeoxyribonucleotides, and enzymes were purchased from commercial suppliers and were used without further purification. Purification of nucleoside triphosphates was performed using HPLC on a column packed with $10 \mu \mathrm{m}$ C18 reversed phase. NMR spectra were measured on a $500 \mathrm{MHz}\left({ }^{1} \mathrm{H}\right.$ at $500.0 \mathrm{MHz},{ }^{13} \mathrm{C}$ at $125.7 \mathrm{MHz}$ and ${ }^{31} \mathrm{P}$ at 202.3 MHz) or a $600 \mathrm{MHz}\left({ }^{1} \mathrm{H}\right.$ at $600.1 \mathrm{MHz}$ and ${ }^{13} \mathrm{C}$ at 150.9 MHz) NMR spectrometer in DMSO- $\mathrm{d}_{6}$ or $\mathrm{D}_{2} \mathrm{O}$ solutions at $25{ }^{\circ} \mathrm{C}$. Chemical shifts (in ppm, $\delta$ scale) were referenced to the residual solvent signal in ${ }^{1} \mathrm{H}$ spectra $\left(\delta\left(\left(\mathrm{CHD}_{2}\right) \mathrm{SO}\left(\mathrm{CD}_{3}\right)\right)=\right.$ $2.5 \mathrm{ppm})$ or to the solvent signal in ${ }^{13} \mathrm{C}$ spectra $\left(\delta\left(\left(\mathrm{CD}_{3}\right)_{2} \mathrm{SO}\right)=\right.$ $39.7 \mathrm{ppm})$. 1,4-Dioxane was used as an internal standard for $\mathrm{D}_{2} \mathrm{O}$ solutions (3.75 ppm for ${ }^{1} \mathrm{H}$ and $69.3 \mathrm{ppm}$ for ${ }^{13} \mathrm{C}$ ). Coupling constants $(J)$ are given in Hz. The complete assignment of ${ }^{1} \mathrm{H}$ and ${ }^{13} \mathrm{C}$ signals was performed by an analysis of the correlated homonuclear $\mathrm{H}, \mathrm{H}-\mathrm{COSY}$, and heteronuclear $\mathrm{H}$, C-HSQC and H,C-HMBC spectra. Known starting compounds $\mathbf{d A}^{\mathbf{I}} \mathbf{T P}, \mathbf{d C}^{\mathbf{I}} \mathbf{T P}, \mathbf{d U}^{\mathbf{N O} 2} \mathbf{T P},{ }^{5} \mathbf{d C}^{\mathbf{E B F}} \mathbf{T P},{ }^{9} \mathbf{E P T},{ }^{37}$ and PT-Bpin ${ }^{38}$ were prepared by published procedures.

\section{Synthesis of modified nucleosides - Suzuki-Miyaura cross-coupling}

$\left(\mathbf{d C}^{\mathbf{P T}}, \mathbf{d A} \mathbf{P}^{\mathbf{P T}}\right)$. Method A: A $1: 1$ mixture of $\mathrm{H}_{2} \mathrm{O}-\mathrm{CH}_{3} \mathrm{CN}$ $(2 \mathrm{~mL})$ was added through a septum to an argon-purged flask containing a halogenated nucleoside $\mathbf{d N}^{\mathbf{I}}$ (1 equiv.), PT-Bpin ( 2 equiv.) and $\mathrm{Cs}_{2} \mathrm{CO}_{3}$ (3 equiv.). In a separate flask, $\mathrm{Pd}(\mathrm{OAc})_{2}$
(10 mol\%), and TPPTS (2.5 equiv. with respect to Pd) were combined, the flask was evacuated and purged with argon, and then a 1:1 mixture of $\mathrm{H}_{2} \mathrm{O}-\mathrm{CH}_{3} \mathrm{CN}(1 \mathrm{~mL})$ was added. This catalyst solution was injected into the reaction mixture, which was then stirred at $50{ }^{\circ} \mathrm{C}$ for $40 \mathrm{~min}$ until complete consumption of the starting material, and then evaporated in vacuo. The products were purified by silica gel column chromatography using chloroform/methanol (100:0 to $90: 10$ ) as the eluent.

\section{Synthesis of modified nucleosides - Sonogashira cross-coupling}

$\left(\mathbf{d C}^{\mathbf{E P T}}\right.$ or $\left.\mathbf{d A}^{\mathbf{E P T}}\right)$. Method B: Dry DMF (3 mL) was added to an argon-purged flask containing PTE (1.5 equiv.), a nucleoside analogue $\mathbf{d N}^{\mathbf{I}}$ (1 equiv.), CuI (10 mol\%) and $\left[\mathrm{Pd}\left(\mathrm{PPh}_{3}\right)_{2} \mathrm{Cl}_{2}\right]$ (5 $\mathrm{mol} \%$ ) followed by $(\mathrm{iPr})_{2} \mathrm{EtN}$ (10 equiv.). The reaction mixture was stirred at $75{ }^{\circ} \mathrm{C}$ for $1 \mathrm{~h}$ until complete consumption of the starting material, and then evaporated in vacuo. The products were purified by silica gel column chromatography using chloroform/methanol $(100: 0$ to $90: 10)$ as the eluent.

\section{Synthesis of modified nucleotides triphosphates - Suzuki-Miyaura cross-coupling}

( $\mathbf{d C}^{\mathbf{P T}} \mathbf{T P}$ or $\left.\mathbf{d A}^{\mathbf{P T}} \mathbf{T P}\right)$. Method C: A $1: 1$ mixture of $\mathrm{H}_{2} \mathrm{O}-$ $\mathrm{CH}_{3} \mathrm{CN}(1 \mathrm{~mL})$ was added through a septum to an argonpurged flask containing a halogenated nucleotide $\mathbf{d N}^{\mathbf{I}} \mathbf{T P}$ (1 equiv.), PT-Bpin (2 equiv.) and $\mathrm{Cs}_{2} \mathrm{CO}_{3}$ (3 equiv.). In a separate flask, $\mathrm{Pd}(\mathrm{OAc})_{2}(10 \mathrm{~mol} \%)$, and TPPTS (2.5 equiv. with respect to $\mathrm{Pd}$ ) were combined, the flask was evacuated and purged with argon, and then a $1: 1$ mixture of $\mathrm{H}_{2} \mathrm{O}-\mathrm{CH}_{3} \mathrm{CN}$ $(0.5 \mathrm{~mL})$ was added. This catalyst solution was injected into the reaction mixture, which was then stirred at $50{ }^{\circ} \mathrm{C}$ for 40 min until complete consumption of the starting material, and then evaporated in vacuo. The product was isolated from the crude reaction mixture by HPLC on a C18 column with the use of a linear gradient of $0.1 \mathrm{M}$ TEAB (triethylammonium bicarbonate) in $\mathrm{H}_{2} \mathrm{O}$ to $0.1 \mathrm{M}$ TEAB in $\mathrm{H}_{2} \mathrm{O}-\mathrm{MeOH}(1: 1)$ as the eluent. Several co-distillations with water and conversion to sodium salt form (Dowex 50WX8 in $\mathrm{Na}^{+}$cycle) followed by freeze-drying from water gave the solid product.

\section{Synthesis of modified nucleotide triphosphates - Sonogashira cross-coupling}

(dC ${ }^{\text {EPT }}$ TP or $\left.\mathbf{d A}^{\mathbf{E P T}} \mathbf{T P}\right)$. Method D: A $1: 1$ mixture of $\mathrm{H}_{2} \mathrm{O}$ $\mathrm{CH}_{3} \mathrm{CN}(2 \mathrm{~mL})$ was added through a septum to an argonpurged flask containing a halogenated nucleotide $\mathbf{d N}^{\mathbf{I}} \mathbf{T P}$ (1 equiv.), PTE (1.5 equiv.), CuI (10 mol\%), and (iPr) $)_{2} \mathrm{EtN}$ (10 equiv.). In a separate flask, $\mathrm{Pd}(\mathrm{OAc})_{2}(5 \mathrm{~mol} \%)$, and TPPTS (2.5 equiv. with respect to $\mathrm{Pd}$ ) were combined, the flask was evacuated and purged with argon, and then a 1:1 mixture of $\mathrm{H}_{2} \mathrm{O}-\mathrm{CH}_{3} \mathrm{CN}(0.5 \mathrm{~mL})$ was added. This catalyst solution was injected into the reaction mixture, which was then stirred at $75{ }^{\circ} \mathrm{C}$ for $1 \mathrm{~h}$ until complete consumption of the starting material, and then evaporated in vacuo. The product was isolated from the crude reaction mixture by HPLC on a C18 
column with the use of a linear gradient of $0.1 \mathrm{M}$ TEAB (triethylammonium bicarbonate) in $\mathrm{H}_{2} \mathrm{O}$ to $0.1 \mathrm{M}$ TEAB in $\mathrm{H}_{2} \mathrm{O}-\mathrm{MeOH}(1: 1)$ as the eluent. Several co-distillations with water and conversion to sodium salt form (Dowex 50WX8 in $\mathrm{Na}^{+}$cycle) followed by freeze-drying from water gave solid product.

\section{Synthesis of modified nucleosides triphosphates - triphosphorylation}

( $\mathbf{d C}^{\mathbf{E P T}} \mathbf{T P}$ or $\left.\mathbf{d} \mathbf{A}^{\mathbf{E P T}} \mathbf{T P}\right)$. Method $\mathbf{E}$ : $\mathrm{POCl}_{3}$ (1.2 equiv.) in $\mathrm{PO}(\mathrm{OMe})_{3}(1 \mathrm{ml})$ was added through a septum to an argonpurged flask containing modified nucleosides $\mathbf{d N}^{\mathbf{E P T}}$ ( 1 equiv.). The reaction mixture was then stirred at $0{ }^{\circ} \mathrm{C}$ for $3 \mathrm{~h}$ until complete consumption of the starting material. Then an ice-cooled solution of $\left(\mathrm{NHBu}_{3}\right)_{2} \mathrm{H}_{2} \mathrm{P}_{2} \mathrm{O}_{7}$ (5 equiv.) and $\mathrm{Bu}_{3} \mathrm{~N}$ (4.2 equiv.) in dry DMF ( $2 \mathrm{ml}$ ) was added and the mixture was stirred at $0{ }^{\circ} \mathrm{C}$ for another $1.5 \mathrm{~h}$. The reaction was quenched by addition of $2 \mathrm{M}$ aqueous TEAB $(2 \mathrm{ml})$, the solvents were evaporated in vacuo and the residue was co-distilled with water three times. The product was isolated by HPLC on a C18 column with the use of a linear gradient of $0.1 \mathrm{M}$ TEAB (triethylammonium bicarbonate) in $\mathrm{H}_{2} \mathrm{O}$ to $0.1 \mathrm{M}$ TEAB in $\mathrm{H}_{2} \mathrm{O}-\mathrm{MeOH}$ $(1: 1)$ as the eluent. Several co-distillations with water and conversion to the sodium salt form (Dowex 50WX8 in $\mathrm{Na}^{+}$cycle) followed by freeze-drying from water gave the solid product.

$\mathbf{d C}^{\mathbf{P T}}$ : Compound $\mathbf{d C ^ { \mathbf { P T } }}$ was prepared from $\mathbf{d C ^ { \mathbf { I } }}$ according to the general procedure (Method A). The product was isolated as a white solid (59 mg, 75\%); m.p. $145{ }^{\circ} \mathrm{C} ;{ }^{1} \mathrm{H}$ NMR $(600.1 \mathrm{MHz}$, DMSO- $\left.d_{6}\right): 2.06\left(\mathrm{ddd}, 1 \mathrm{H}, J_{\text {gem }}=13.2, J_{2^{\prime} \mathrm{b}, 1^{\prime}}=7.2, J_{2^{\prime} \mathrm{b}, 3^{\prime}}=6.1\right.$, $\left.\mathrm{H}-2^{\prime} \mathrm{b}\right) ; 2.13$ (ddd, $\left.1 \mathrm{H}, J_{\text {gem }}=13.2, J_{2^{\prime} \mathrm{a}, 1^{\prime}}=6.1, J_{2^{\prime} \mathrm{a}, 3^{\prime}}=3.7, \mathrm{H}-2^{\prime} \mathrm{a}\right)$; $3.33\left(\mathrm{~s}, 3 \mathrm{H}, \mathrm{CH}_{3} \mathrm{~N}\right) ; 3.49,3.54\left(2 \times \mathrm{ddd}, 2 \times 1 \mathrm{H}, J_{\text {gem }}=11.8\right.$, $\left.J_{5^{\prime}, \mathrm{OH}}=5.1, J_{5^{\prime}, 4^{\prime}}=3.7, \mathrm{H}-5^{\prime}\right) ; 3.76\left(\mathrm{q}, 1 \mathrm{H}, J_{4^{\prime}, 3^{\prime}}=J_{4^{\prime}, 5^{\prime}}=3.7, \mathrm{H}-4^{\prime}\right)$; $4.23\left(\mathrm{ddt}, 1 \mathrm{H}, J_{3^{\prime}, 2^{\prime}}=6.1,3.7, J_{3^{\prime}, \mathrm{OH}}=4.3, J_{3^{\prime}, 4^{\prime}}=3.7, \mathrm{H}-3^{\prime}\right) ; 4.91$ $\left(\mathrm{t}, 1 \mathrm{H}, J_{\mathrm{OH}, 5^{\prime}}=5.1, \mathrm{OH}-5^{\prime}\right) ; 5.17\left(\mathrm{~d}, 1 \mathrm{H}, J_{\mathrm{OH}, 3^{\prime}}=4.3, \mathrm{OH}-3^{\prime}\right) ; 6.20$ $\left(\mathrm{dd}, 1 \mathrm{H}, J_{1^{\prime}, 2^{\prime}}=7.2,6.1, \mathrm{H}-1^{\prime}\right) ; 6.37$ (bs, $1 \mathrm{H}, \mathrm{NH}_{\mathrm{a}} \mathbf{H}_{\mathbf{b}}$ ); 6.94-7.01 (m, 3H, H-1,7,9-phenothiazine); 7.09 (d, 1H, $J_{4,2}=2.1$, H-4-phenothiazine); 7.14 (dd, $1 \mathrm{H}, J_{2,1}=8.3, J_{2,4}=2.1$, H-2-phenothiazine); 7.17 (m, 1H, H-6-phenothiazine); 7.23 (m, 1H, H-8phenothiazine); 7.31 (bs, $\left.1 \mathrm{H}, \mathrm{NH}_{\mathrm{a}} \mathrm{H}_{\mathrm{b}}\right) ; 7.77$ (s, 1H, H-6). ${ }^{13} \mathrm{C}$ NMR (150.9 MHz, DMSO- $\left.d_{6}\right)$ : $35.34\left(\mathrm{CH}_{3} \mathrm{~N}\right) ; 40.66\left(\mathrm{CH}_{2}-2^{\prime}\right)$; $61.23\left(\mathrm{CH}_{2}-5^{\prime}\right) ; 70.36\left(\mathrm{CH}-3^{\prime}\right) ; 85.18\left(\mathrm{CH}^{\prime} \mathbf{1}^{\prime}\right) ; 87.39$ (CH-4'); 106.93 (C-5); 114.77 (CH-9-phenothiazine); 114.96 (CH-1phenothiazine); 122.17 (C-5a-phenothiazine); 122.72 (CH-7phenothiazine); 122.77 (C-4a-phenothiazine); 127.00 (CH-6phenothiazine); 127.46 (CH-4-phenothiazine); 127.97 (CH-8phenothiazine); 128.26 (C-3-phenothiazine); 128.60 (CH-2phenothiazine); 139.83 (CH-6); 144.95 (C-10a-phenothiazine); 145.29 (C-9a-phenothiazine); 154.60 (C-2); 163.66 (C-4). MS (ESI+): $m / z$ (\%): 461.1 (100) $\left[\mathrm{M}^{+}+\mathrm{Na}\right]$; HRMS (ESI+): calcd 439.14345 for $\mathrm{C}_{22} \mathrm{H}_{23} \mathrm{~N}_{4} \mathrm{O}_{4} \mathrm{~S}$, found 439.14365; calcd 461.12540 for $\mathrm{C}_{22} \mathrm{H}_{22} \mathrm{~N}_{4} \mathrm{O}_{4} \mathrm{NaS}$, found 461.12549.

$\mathbf{d A}^{\mathbf{P T}}$ : Compound $\mathbf{d} \mathbf{A}^{\mathbf{P T}}$ was prepared from $\mathbf{d} \mathbf{A}^{\mathbf{I}}$ according to the general procedure (Method A). The product was isolated as a white solid (52 mg, 96\%); m.p. $204{ }^{\circ} \mathrm{C} ;{ }^{1} \mathrm{H}$ NMR $(500.0 \mathrm{MHz}$, DMSO- $\left.d_{6}\right): 2.18\left(\mathrm{ddd}, 1 \mathrm{H}, J_{\text {gem }}=13.1, J_{2^{\prime} \mathrm{b}, 1^{\prime}}=6.0, J_{2^{\prime} \mathrm{b}, 3^{\prime}}=2.6\right.$, $\left.\mathrm{H}-2^{\prime} \mathrm{b}\right) ; 2.55$ (ddd, $\left.1 \mathrm{H}, J_{\text {gem }}=13.1, J_{2^{\prime} \mathrm{a}, 1^{\prime}}=8.3, J_{2^{\prime} \mathrm{a}, 3^{\prime}}=5.8, \mathrm{H}-2^{\prime} \mathrm{a}\right)$; $3.35\left(\mathrm{~s}, 3 \mathrm{H}, \mathrm{CH}_{3} \mathrm{~N}\right) ; 3.50\left(\mathrm{dd}, 1 \mathrm{H}, J_{\text {gem }}=11.7, J_{5^{\prime} \mathrm{b}, 4^{\prime}}=4.4, \mathrm{H}-5^{\prime} \mathrm{b}\right)$; $3.57\left(\mathrm{dd}, 1 \mathrm{H}, J_{\text {gem }}=11.7, J_{5^{\prime} \mathrm{a}, 4^{\prime}}=4.7, \mathrm{H}-5^{\prime} \mathrm{a}\right) ; 3.84(\mathrm{ddd}, 1 \mathrm{H}$, $\left.J_{4^{\prime}, 5^{\prime}}=4.7,4.4, J_{4^{\prime}, 3^{\prime}}=2.6, \mathrm{H}-4^{\prime}\right) ; 4.35\left(\mathrm{dt}, 1 \mathrm{H}, J_{3^{\prime}, 2^{\prime}}=5.8,2.6\right.$, $\left.J_{3^{\prime}, 4^{\prime}}=2.6, \mathrm{H}-3^{\prime}\right) ; 5.05$ (bs, $\left.1 \mathrm{H}, \mathrm{OH}-5^{\prime}\right) ; 5.27$ (bs, $\left.1 \mathrm{H}, \mathrm{OH}-3^{\prime}\right) ; 6.17$ (bs, $\left.2 \mathrm{H}, \mathrm{NH}_{2}\right) ; 6.57\left(\mathrm{dd}, 1 \mathrm{H}, J_{1^{\prime}, 2^{\prime}}=8.3,6.0, \mathrm{H}-1^{\prime}\right) ; 6.94-7.02(\mathrm{~m}$, $2 \mathrm{H}, \mathrm{H}-7,9-$ phenothiazine); $7.06\left(\mathrm{~d}, 1 \mathrm{H}, J_{1,2}=8.3, \mathrm{H}-1-\right.$ phenothiazine); 7.18 (dd, $1 \mathrm{H}, J_{6,7}=7.5, J_{6,8}=1.5$, H-6-phenothiazine); 7.24 (ddd, $1 \mathrm{H}, J_{8,9}=8.2, J_{8,7}=7.3, J_{8,6}=1.5$, H-8phenothiazine); $7.26\left(\mathrm{~d}, 1 \mathrm{H}, J_{4,2}=2.0, \mathrm{H}-4\right.$-phenothiazine); $7.28\left(\mathrm{dd}, 1 \mathrm{H}, J_{2,1}=8.3, J_{2,4}=2.0, \mathrm{H}\right.$-2-phenothiazine); $7.50(\mathrm{~s}$, $1 \mathrm{H}, \mathrm{H}-6) ; 8.14$ (bs, $1 \mathrm{H}, \mathrm{H}-2) .{ }^{13} \mathrm{C}$ NMR (125.7 MHz, DMSO- $d_{6}$ ): $35.39\left(\mathrm{CH}_{3} \mathrm{~N}\right) ; 39.81\left(\mathrm{CH}_{2}-2^{\prime}\right) ; 62.20\left(\mathrm{CH}_{2}-5^{\prime}\right) ; 71.25\left(\mathrm{CH}-3^{\prime}\right)$; 83.06 (CH-1'); 87.54 (CH-4'); 100.55 (C-4a); 114.84 (CH-9-phenothiazine); 115.11 (CH-1-phenothiazine); 115.56 (C-5); 120.59 (CH-6); 121.96 (C-5a-phenothiazine); 122.73 (CH-7-phenothiazine); 122.92 (C-4a-phenothiazine); 126.77 (CH-2-phenothiazine); 127.06 (CH-6-phenothiazine); 127.93 (CH-4-phenothiazine); 128.05 (CH-8-phenothiazine); 128.90 (C-3-phenothiazine); 144.32 (C-10a-phenothiazine); 145.42 (C-9a-phenothiazine); 150.57 (C-7a); 151.80 (CH-2); 157.49 (C-4). MS (ESI+): $m / z$ (\%): 462.1 (40) $\left[\mathrm{M}^{+}+\mathrm{H}\right]$; 484.1 (100) $\left[\mathrm{M}^{+}+\mathrm{Na}\right]$; HRMS (ESI+): calcd 462.15944 for $\mathrm{C}_{24} \mathrm{H}_{24} \mathrm{~N}_{5} \mathrm{O}_{3} \mathrm{~S}$, found 462.15934 ; calcd 484.14138 for $\mathrm{C}_{24} \mathrm{H}_{23} \mathrm{O}_{3} \mathrm{~N}_{5} \mathrm{NaS}$, found 484.14141.

$\mathbf{d C}^{\mathbf{E P T}}$ : Compound $\mathbf{d C}^{\mathbf{E P T}}$ was prepared from $\mathbf{d C ^ { \mathbf { I } }}$ according to the general procedure (Method B). The product was isolated as a yellow solid (54 mg, 76\%); m.p. $143{ }^{\circ} \mathrm{C} ;{ }^{1} \mathrm{H}$ NMR $\left(600.1 \mathrm{MHz}, \mathrm{DMSO}-d_{6}\right): 2.02\left(\mathrm{ddd}, 1 \mathrm{H}, J_{\text {gem }}=13.1, J_{2^{\prime} \mathrm{b}, 1^{\prime}}=7.0\right.$, $\left.J_{2^{\prime} \mathrm{b}, 3^{\prime}}=6.2, \mathrm{H}-2^{\prime} \mathrm{b}\right) ; 2.17\left(\mathrm{ddd}, 1 \mathrm{H}, J_{\text {gem }}=13.1, J_{2^{\prime} \mathrm{a}, 1^{\prime}}=6.0, J_{2^{\prime} \mathrm{a}, 3^{\prime}}=\right.$ 3.6, H-2'a); $3.33\left(\mathrm{~s}, 3 \mathrm{H}, \mathrm{CH}_{3} \mathrm{~N}\right) ; 3.58,3.65(2 \times \mathrm{ddd}, 2 \times 1 \mathrm{H}$, $\left.J_{\text {gem }}=11.8, J_{5^{\prime}, \mathrm{OH}}=5.0, J_{5^{\prime}, 4^{\prime}}=3.6, \mathrm{H}-5^{\prime}\right) ; 3.80\left(\mathrm{q}, 1 \mathrm{H}, J_{4^{\prime}, 3^{\prime}}=J_{4^{\prime}, 5^{\prime}}\right.$ $\left.=3.6, \mathrm{H}-4^{\prime}\right)$; $4.23\left(\mathrm{ddt}, 1 \mathrm{H}, J_{3^{\prime}, 2^{\prime}}=6.2,3.6, J_{3^{\prime}, \mathrm{OH}}=4.3, J_{3^{\prime}, 4^{\prime}}=3.6\right.$, $\left.\mathrm{H}-3^{\prime}\right) ; 5.11\left(\mathrm{t}, 1 \mathrm{H}, J_{\mathrm{OH}, 5^{\prime}}=5.0, \mathrm{OH}-5^{\prime}\right) ; 5.21\left(\mathrm{~d}, 1 \mathrm{H}, J_{\mathrm{OH}, 3^{\prime}}=4.3\right.$, $\left.\mathrm{OH}-3^{\prime}\right) ; 6.13\left(\mathrm{dd}, 1 \mathrm{H}, J_{1^{\prime}, 2^{\prime}}=7.0,6.0, \mathrm{H}^{-1}{ }^{\prime}\right) ; 6.95\left(\mathrm{~d}, 1 \mathrm{H}, J_{1,2}=\right.$ 8.5, H-1-phenothiazine); 6.97-7.00 (m, 2H, H-7,9-phenothiazine); 7.01 (bs, $1 \mathrm{H}, \mathrm{NH}_{\mathrm{a}} \mathbf{H}_{\mathbf{b}}$ ); $7.17\left(\mathrm{dd}, 1 \mathrm{H}, J_{6,7}=7.8, J_{6,8}=1.5\right.$, H-6-phenothiazine); $7.23\left(\mathrm{ddd}, 1 \mathrm{H}, J_{8,9}=8.2, J_{8,7}=7.4, J_{8,6}=\right.$ 1.5, H-8-phenothiazine); 7.41 (dd, $1 \mathrm{H}, J_{2,1}=8.5, J_{2,4}=2.0, \mathrm{H}-2$ phenothiazine); $7.44\left(\mathrm{~d}, 1 \mathrm{H}, J_{4,2}=2.0, \mathrm{H}-4\right.$-phenothiazine); 7.76 (bs, $1 \mathrm{H}, \mathrm{NH}_{\mathrm{a}} \mathrm{H}_{\mathrm{b}}$ ); 8.27 (s, 1H, H-6). ${ }^{13} \mathrm{C} \mathrm{NMR}(150.9 \mathrm{MHz}$, DMSO- $\left.d_{6}\right): 35.44\left(\mathrm{CH}_{3} \mathrm{~N}\right) ; 41.00\left(\mathrm{CH}_{2}-2^{\prime}\right) ; 61.08\left(\mathrm{CH}_{2}-5^{\prime}\right) ; 70.13$ (CH-3'); 81.64 (C5-C $\equiv \mathrm{C}-$ phenothiazine); 85.55 (CH-1'); 87.58 $\left(\mathrm{CH}-4^{\prime}\right) ; 89.90$ (C-5); 93.30 (C5-C $\equiv$ C-phenothiazine); 114.63 (CH-1-phenothiazine); 115.08 (CH-9-phenothiazine); 116.50 (C-3-phenothiazine); 121.54 (C-5a-phenothiazine); 122.28 (C-4a-phenothiazine); 123.04 (CH-7-phenothiazine); 127.02 (CH-6-phenothiazine); 128.11 (CH-8-phenothiazine); 129.32 (CH-4-phenothiazine); 130.99 (CH-2-phenothiazine); 144.59 (CH-6); 144.82 (C-9a-phenothiazine); 145.46 (C-10a-phenothiazine); 153.53 (C-2); 163.91 (C-4). MS (ESI-): $m / z$ (\%):461.1 (100) $[\mathrm{M}-\mathrm{H}]$; HRMS (ESI-): calcd 461.12890 for $\mathrm{C}_{24} \mathrm{H}_{21} \mathrm{~N}_{4} \mathrm{O}_{4} \mathrm{~S}$, found 461.12835 .

$\mathbf{d} \mathbf{A}^{\mathbf{E P T}}$ : Compound $\mathbf{d} \mathbf{A}^{\mathbf{E P T}}$ was prepared from $\mathbf{d} \mathbf{A}^{\mathbf{I}}$ according to the general procedure (Method B). The product was isolated as a yellow solid (50 mg, 93\%); m.p. $208{ }^{\circ} \mathrm{C}$; ${ }^{1} \mathrm{H}$ NMR $\left(600.1 \mathrm{MHz}, \mathrm{DMSO}-d_{6}\right): 2.20\left(\mathrm{ddd}, 1 \mathrm{H}, J_{\text {gem }}=13.1, J_{2^{\prime} \mathrm{b}, 1^{\prime}}=6.0\right.$, $\left.J_{2^{\prime} \mathrm{b}, 3^{\prime}}=2.8, \mathrm{H}-2^{\prime} \mathrm{b}\right) ; 2.49\left(\mathrm{ddd}, 1 \mathrm{H}, J_{\text {gem }}=13.1, J_{2^{\prime} \mathrm{a}, 1^{\prime}}=8.0, J_{2^{\prime} \mathrm{a}, 3^{\prime}}=\right.$ 
5.7, H-2'a); $3.34\left(\mathrm{~s}, 3 \mathrm{H}, \mathrm{CH}_{3} \mathrm{~N}\right) ; 3.53\left(\mathrm{ddd}, 1 \mathrm{H}, J_{\text {gem }}=11.8\right.$, $\left.J_{5^{\prime} \mathrm{b}, \mathrm{OH}}=5.9, J_{5^{\prime} \mathrm{b}, 4^{\prime}}=4.4, \mathrm{H}-5^{\prime} \mathrm{b}\right) ; 3.59\left(\mathrm{ddd}, 1 \mathrm{H}, J_{\text {gem }}=11.8\right.$, $\left.J_{5^{\prime} \mathrm{a}, \mathrm{OH}}=5.3, J_{5^{\prime} \mathrm{a}, 4^{\prime}}=4.4, \mathrm{H}-5^{\prime} \mathrm{a}\right) ; 3.84\left(\mathrm{td}, 1 \mathrm{H}, J_{4^{\prime}, 5^{\prime}}=4.4, J_{4^{\prime}, 3^{\prime}}=\right.$ $\left.2.5, \mathrm{H}-4^{\prime}\right) ; 4.35$ (dddd, $1 \mathrm{H}, J_{3^{\prime}, 2^{\prime}}=5.7,2.8, J_{3^{\prime}, \mathrm{OH}}=4.1, J_{3^{\prime}, 4^{\prime}}=2.5$, $\left.\mathrm{H}-3^{\prime}\right) ; 5.06\left(\mathrm{dd}, 1 \mathrm{H}, J_{\mathrm{OH}, 5^{\prime}}=5.9,5.3, \mathrm{OH}^{\prime} 5^{\prime}\right) ; 5.27\left(\mathrm{~d}, 1 \mathrm{H}, J_{\mathrm{OH}, 3^{\prime}}=\right.$ 4.1, OH-3'); 6.51 (dd, $\left.1 \mathrm{H}, J_{1^{\prime}, 2^{\prime}}=8.0,6.0, \mathrm{H}-1^{\prime}\right) ; 6.69$ (bs, $2 \mathrm{H}$, $\mathrm{NH}_{2}$ ); 6.95-7.01 (m, 3H, H-1,7,9-phenothiazine); 7.17 (dd, 1H, $J_{6,7}=7.8, J_{6,8}=1.5$, H-6-phenothiazine); 7.24 (ddd, $1 \mathrm{H}, J_{8,9}=$ $8.2, J_{8,7}=7.3, J_{8,6}=1.5, \mathrm{H}-8$-phenothiazine); $7.40\left(\mathrm{~d}, 1 \mathrm{H}, J_{4,2}=\right.$ 2.0, H-4-phenothiazine); $7.42\left(\mathrm{dd}, 1 \mathrm{H}, J_{2,1}=8.4, J_{2,4}=2.0\right.$, H-2phenothiazine); 7.83 (s, 1H, H-6); 8.20 (bs, $1 \mathrm{H}, \mathrm{H}-2) .{ }^{13} \mathrm{C}$ NMR $\left(150.9 \mathrm{MHz}, \mathrm{DMSO}-d_{6}\right)$ : $35.43\left(\mathrm{CH}_{3} \mathrm{~N}\right) ; 40.04\left(\mathrm{CH}_{2}-2^{\prime}\right) ; 62.05$ $\left(\mathrm{CH}_{2}-5^{\prime}\right) ; 71.12$ (CH-3'); 82.97 (C5-C $\equiv$ C-phenothiazine); 83.35 $\left(\mathrm{CH}-1^{\prime}\right) ; 87.71$ (CH-4'); 90.57 (C5-C $\equiv$ C-phenothiazine); 95.18 (C-5); 102.50 (C-4a); 114.79 (CH-1-phenothiazine); 115.07 (CH-9-phenothiazine); 116.50 (C-3-phenothiazine); 121.56 (C-5a-phenothiazine); 122.54 (C-4a-phenothiazine); 123.05 (CH-7-phenothiazine); 126.64 (CH-6); 127.03 (CH-6-phenothiazine); 128.11 (CH-8-phenothiazine); 129.16 (CH-4-phenothiazine); 131.06 (CH-2-phenothiazine); 144.82 (C-9a-phenothiazine); 145.53 (C-10a-phenothiazine); 149.54 (C-7a); 152.83 (CH-2); 157.81 (C-4). MS (ESI-): $m / z$ (\%): 484.1 (30) [M - H]; HRMS (ESI-): calcd 484.14488 for $\mathrm{C}_{26} \mathrm{H}_{22} \mathrm{~N}_{5} \mathrm{O}_{3} \mathrm{~S}$, found 484.14429.

$\mathbf{d C}^{\mathbf{P T}} \mathbf{T P}$ : Compound $\mathbf{d C}^{\mathbf{P T}}$ was prepared from $\mathbf{d C}^{\mathbf{I}} \mathbf{T P}$ according to the general procedure (Method $\mathrm{C}$ ). The product was isolated as a white solid (30 mg, 53\%); ${ }^{1} \mathrm{H} \mathrm{NMR}\left(500.0 \mathrm{MHz}, \mathrm{D}_{2} \mathrm{O}\right.$, $\operatorname{ref}($ dioxane $)=3.75 \mathrm{ppm}): 2.35\left(\mathrm{ddd}, 1 \mathrm{H}, J_{\text {gem }}=14.0, J_{2^{\prime} \mathrm{b}, 1^{\prime}}=\right.$ $\left.7.5, J_{2^{\prime} \mathrm{b}, 3^{\prime}}=6.6, \mathrm{H}-2^{\prime} \mathrm{b}\right) ; 2.42\left(\mathrm{ddd}, 1 \mathrm{H}, J_{\text {gem }}=14.0, J_{2^{\prime} \mathrm{a}, 1^{\prime}}=6.3\right.$, $\left.J_{2^{\prime} \mathrm{a}, 3^{\prime}}=3.6, \mathrm{H}-2^{\prime} \mathrm{a}\right) ; 3.38$ (s, 3H, $\left.\mathrm{CH}_{3} \mathrm{~N}\right)$; 4.11-4.19 (m, 2H, H-5'); $4.22\left(\mathrm{tdd}, 1 \mathrm{H}, J_{4^{\prime}, 5^{\prime}}=4.2, J_{4^{\prime}, 3^{\prime}}=3.6, J_{\mathrm{H}, \mathrm{P}}=1.2, \mathrm{H}-4^{\prime}\right) ; 4.60(\mathrm{dt}$, $\left.1 \mathrm{H}, J_{3^{\prime}, 2^{\prime}}=6.6,3.6, J_{3^{\prime}, 4^{\prime}}=3.6, \mathrm{H}-3^{\prime}\right) ; 6.31\left(\mathrm{dd}, 1 \mathrm{H}, J_{1^{\prime}, 2^{\prime}}=7.5,6.3\right.$, $\mathrm{H}-1^{\prime}$ ); 7.01 (dd, $1 \mathrm{H}, J_{9,8}=8.2, J_{9,7}=1.2$, H-9-phenothiazine); 7.02-7.09 (m, 2H, H-1,7-phenothiazine); 7.11 (d, 1H, $J_{4,2}=2.1$, $\mathrm{H}$-4-phenothiazine); $7.23\left(\mathrm{dd}, 1 \mathrm{H}, J_{2,1}=8.4, J_{2,4}=2.1, \mathrm{H}-2\right.$ phenothiazine); 7.24-7.33 (m, 2H, H-6,8-phenothiazine); 7.61 (s, 1H, H-6). ${ }^{13} \mathrm{C}$ NMR (125.7 MHz, $\mathrm{D}_{2} \mathrm{O}$, ref(dioxane) = $69.3 \mathrm{ppm})$ : $37.47\left(\mathrm{CH}_{3} \mathrm{~N}\right) ; 41.52\left(\mathrm{CH}_{2}-2^{\prime}\right) ; 68.02\left(\mathrm{~d}, J_{\mathrm{C}, \mathrm{P}}=5.5\right.$, $\left.\mathrm{CH}_{2}-5^{\prime}\right) ; 73.31\left(\mathrm{CH}-3^{\prime}\right) ; 88.20\left(\mathrm{~d}, J_{\mathrm{C}, \mathrm{P}}=8.5, \mathrm{CH}-4^{\prime}\right) ; 88.77\left(\mathrm{CH}-1^{\prime}\right)$; 112.32 (C-5); 117.48 (CH-9-phenothiazine); 117.95 (CH-1phenothiazine); 124.97 (C-5a-phenothiazine); 125.85 (CH-7phenothiazine); 126.16 (C-4a-phenothiazine); 129.16 (C-3phenothiazine); 129.96 (CH-6-phenothiazine); 130.09 (CH-4phenothiazine); 130.88 (CH-8-phenothiazine); 131.73 (CH-2phenothiazine); 142.14 (CH-6); 148.12 (C-9a-phenothiazine); 148.65 (C-10a-phenothiazine); 159.73 (C-2); 167.20 (C-4). ${ }^{31} \mathrm{P}\left\{{ }^{1} \mathrm{H}\right\}$ NMR (202.3 MHz, $\left.\mathrm{D}_{2} \mathrm{O}\right):-22.04\left(\mathrm{dd}, J=20.0,19.6, \mathrm{P}_{\beta}\right)$; -11.22 (d, $J=19.6, \mathrm{P}_{\alpha}$ ); -6.39 (d, $J=20.0, \mathrm{P}_{\gamma}$ ). MS (ESI-): $m / z$ (\%): 597.1 (100) [M - $\left.\mathrm{H}-\mathrm{H}_{2} \mathrm{PO}_{3}\right]$; HRMS (ESI-): calcd 677.02789 for $\mathrm{C}_{22} \mathrm{H}_{24} \mathrm{O}_{13} \mathrm{~N}_{4} \mathrm{P}_{3} \mathrm{~S}$, found 677.02661.

$\mathbf{d A}^{\mathbf{P T}} \mathbf{T P}$ : Compound $\mathbf{d} \mathbf{A}^{\mathbf{P T}}$ was prepared from $\mathbf{d} \mathbf{A}^{\mathbf{I}} \mathbf{T P}$ according to the general procedure (Method $\mathrm{C}$ ). The product was isolated as a white solid (38 mg, 68\%); ${ }^{1} \mathrm{H}$ NMR $(500.0 \mathrm{MHz}$, $\left.\mathrm{D}_{2} \mathrm{O}\right): 2.55\left(\mathrm{ddd}, 1 \mathrm{H}, J_{\text {gem }}=13.9, J_{2^{\prime} \mathrm{b}, 1^{\prime}}=6.2, J_{2^{\prime} \mathrm{b}, 3^{\prime}}=3.4, \mathrm{H}-2^{\prime} \mathrm{b}\right)$; $2.81\left(\mathrm{ddd}, 1 \mathrm{H}, J_{\text {gem }}=13.9, J_{2^{\prime} \mathrm{a}, 1^{\prime}}=7.8, J_{2^{\prime} \mathrm{a}, 3^{\prime}}=7.0, \mathrm{H}-2^{\prime} \mathrm{a}\right) ; 3.18$ (bs, $\left.3 \mathrm{H}, \mathrm{CH}_{3} \mathrm{~N}\right)$; 4.11-4.24 (m, 2H, H-5'); $4.19\left(\mathrm{td}, 1 \mathrm{H}, J_{4^{\prime}, 5^{\prime}}=\right.$ $\left.4.4, J_{4^{\prime}, 3^{\prime}}=3.5, \mathrm{H}-4^{\prime}\right) ; 4.79\left(\mathrm{~m}, 1 \mathrm{H}, \mathrm{H}-3^{\prime}\right) ; 6.59\left(\mathrm{dd}, 1 \mathrm{H}, J_{1^{\prime}, 2^{\prime}}=7.8\right.$, 6.2, $\left.\mathrm{H}-1^{\prime}\right) ; 6.74-6.83$ (m, 3H, H-1,4,9-phenothiazine); 7.00 $\left(\mathrm{t}, 1 \mathrm{H}, J_{7,6}=J_{7,8}=7.5\right.$, H-7-phenothiazine); 7.18-7.27 (m, 3H, $\mathrm{H}-2,6,8-$ phenothiazine); 7.41 (s, 1H, H-6); 8.06 (bs, 1H, H-2). ${ }^{13} \mathrm{C}$ NMR (150.9 MHz, D $\left.2 \mathrm{O}\right): 37.27\left(\mathrm{CH}_{3} \mathrm{~N}\right) ; 40.72\left(\mathrm{CH}_{2}-2^{\prime}\right)$; $68.30\left(\mathrm{~d}, J_{\mathrm{C}, \mathrm{P}}=6.0, \mathrm{CH}_{2}-5^{\prime}\right) ; 73.75\left(\mathrm{CH}^{-} 3^{\prime}\right) ; 85.27\left(\mathrm{CH}-1^{\prime}\right) ; 87.74$ $\left(\mathrm{d}, J_{\mathrm{C}, \mathrm{P}}=8.6, \mathrm{CH}-4^{\prime}\right)$; 103.39 (C-4a); 117.22 (CH-9-phenothiazine); 117.57 (CH-1-phenothiazine); 119.88 (C-5); 122.21 (CH-6); 124.72 (C-5a-phenothiazine); 125.55 (CH-7-phenothiazine); 125.66 (C-4a-phenothiazine); 129.27 (CH-4-phenothiazine); 129.84 (CH-6-phenothiazine); 130.45 (CH-2-phenothiazine); 130.49 (C-3-phenothiazine); 130.64 (CH-8-phenothiazine); 147.29 (C-10a-phenothiazine); 147.94 (C-9a-phenothiazine); 152.48 (C-7a); 153.94 (CH-2); 159.68 (C-4). ${ }^{31} \mathrm{P}\left\{{ }^{1} \mathrm{H}\right\}$ NMR $\left(202.3 \mathrm{MHz}, \mathrm{D}_{2} \mathrm{O}\right)$ : $-21.75\left(\mathrm{dd}, J=20.1,19.2, \mathrm{P}_{\beta}\right) ;-10.88$ (d, $\left.J=19.2, \mathrm{P}_{\alpha}\right) ;-5.83\left(\mathrm{~d}, J=20.1, \mathrm{P}_{\gamma}\right) . \mathrm{MS}(\mathrm{ESI}-): \mathrm{m} / z(\%)$ : 620.1 (100) [M - H - $\mathrm{H}_{2} \mathrm{PO}_{3}$ ]; HRMS (ESI-): calcd 700.04387 for $\mathrm{C}_{24} \mathrm{H}_{25} \mathrm{O}_{12} \mathrm{~N}_{5} \mathrm{P}_{3} \mathrm{~S}$, found 700.04255 .

$\mathbf{d C}^{\mathbf{E P T}} \mathbf{T P}$ : Compound $\mathbf{d C}^{\mathbf{E P T}}$ was prepared from $\mathbf{d C}^{\mathbf{I}} \mathbf{T P}$ according to Method D in $48 \%$ yield or from $\mathbf{d C}^{\mathbf{E P T}}$ according to Method $\mathrm{E}$ in $45 \%$ yield. The product was isolated as a yellow solid. ${ }^{1} \mathrm{H}$ NMR (500.0 MHz, $\mathrm{D}_{2} \mathrm{O}, \operatorname{ref}($ dioxane $\left.)=3.75 \mathrm{ppm}\right)$ : 2.23 (bm, 1H, H-2'b); 2.36 (bm, $\left.1 \mathrm{H}, \mathrm{H}-2^{\prime} \mathrm{a}\right) ; 3.28\left(\mathrm{~s}, 3 \mathrm{H}, \mathrm{CH}_{3} \mathrm{~N}\right)$; 4.12-4.25 (m, 3H, H-4', $\left.5^{\prime}\right) ; 4.54\left(\mathrm{bm}, 1 \mathrm{H}, \mathrm{H}-3^{\prime}\right) ; 6.11$ (bt, $1 \mathrm{H}$, $\left.J_{1^{\prime}, 2^{\prime}}=6.7, \mathrm{H}-1^{\prime}\right) ; 6.85$ (bd, $1 \mathrm{H}, J_{1,2}=8.0, \mathrm{H}-1$-phenothiazine); 6.91 (bd, 1H, $J_{9,8}=7.9, \mathrm{H}-9$-phenothiazine); 6.99 (bt, 1H, $J_{7,6}=$ $J_{7,8}=7.9, \mathrm{H}-7-$ phenothiazine); 7.16 (bd, $1 \mathrm{H}, J_{6,7}=7.9$, H-6phenothiazine); 7.21-7.26 (bm, 2H, H-4,8-phenothiazine); 7.37 (bd, $1 \mathrm{H}, J_{2,1}=8.0$, H-2-phenothiazine); $7.96(\mathrm{~s}, 1 \mathrm{H}, \mathrm{H}-6)$. ${ }^{13} \mathrm{C}$ NMR (125.7 MHz, $\mathrm{D}_{2} \mathrm{O}$, ref(dioxane) $\left.=69.3 \mathrm{ppm}\right): 37.50$ $\left(\mathrm{CH}_{3} \mathrm{~N}\right) ; 41.62\left(\mathrm{CH}_{2}-2^{\prime}\right) ; 67.91\left(\mathrm{~d}, J_{\mathrm{C}, \mathrm{P}}=5.0, \mathrm{CH}_{2}-5^{\prime}\right) ; 72.88$ $\left(\mathrm{CH}-3^{\prime}\right) ; 81.98$ (C5-C $\equiv$ C-phenothiazine); 88.09 (d, J $J_{\mathrm{C}, \mathrm{P}}=8.4$, $\left.\mathrm{CH}-4^{\prime}\right)$; 89.10 (CH-1'); 95.59 (C-5); 97.96 (C5-C $\equiv$ C-phenothiazine); 117.14 (CH-1-phenothiazine); 117.50 (CH-9-phenothiazine); 118.32 (C-3-phenothiazine); 124.36 (C-5a-phenothiazine); 125.18 (C-4a-phenothiazine); 125.86 (CH-7-phenothiazine); 129.80 (CH-6-phenothiazine); 130.82 (CH-8-phenothiazine); 132.15 (CH-4-phenothiazine); 134.24 (CH-2-phenothiazine); 146.45 (CH-6); 147.55 (C-9a-phenothiazine); 148.77 (C-10aphenothiazine); 158.49 (C-2); 167.22 (C-4). ${ }^{31} \mathrm{P}\left\{{ }^{1} \mathrm{H}\right\} \quad$ NMR (202.3 MHz, $\mathrm{D}_{2} \mathrm{O}$ ): -21.55 (bs, $\mathrm{P}_{\beta}$ ); -10.91 (bs, $\mathrm{P}_{\alpha}$ ); -5.70 (bs, $\mathrm{P}_{\gamma}$ ). MS (ESI-): $m / z$ (\%): 621.1 (100) [M - H - $\left.\mathrm{H}_{2} \mathrm{PO}_{3}\right]$; HRMS (ESI-): calcd 701.02789 for $\mathrm{C}_{24} \mathrm{H}_{24} \mathrm{O}_{13} \mathrm{~N}_{4} \mathrm{P}_{3}$ S, found 701.02649 .

$\mathbf{d A}^{\mathbf{E P T}} \mathbf{T P}$ : Compound $\mathbf{d A}^{\mathbf{E P T}}$ was prepared from $\mathbf{d A} \mathbf{A}^{\mathbf{I}} \mathbf{T P}$ according to Method D in $49 \%$ yield or from $\mathbf{d A} \mathbf{A}^{\mathbf{E P T}}$ according to Method $\mathrm{E}$ in $43 \%$ yield. The product was isolated as a yellow solid. ${ }^{1} \mathrm{H}$ NMR (500.0 MHz, $\left.\mathrm{D}_{2} \mathrm{O}\right): 2.35,2.50(2 \times \mathrm{bm}, 2 \times 1 \mathrm{H}$, $\mathrm{H}-2^{\prime}$ ); 3.02 (bs, 3H, $\mathrm{CH}_{3} \mathrm{~N}$ ); 4.03-4.17 (bm, 2H, H-5'); 4.19 (btd, $\left.1 \mathrm{H}, J_{4^{\prime}, 5^{\prime}}=4.4, J_{4^{\prime}, 3^{\prime}}=3.5, \mathrm{H}-4^{\prime}\right) ; 4.61\left(\mathrm{bm}, 1 \mathrm{H}, \mathrm{H}-3^{\prime}\right) ; 6.20$ (bt, $\left.1 \mathrm{H}, J_{1^{\prime}, 2^{\prime}}=6.2, \mathrm{H}-1^{\prime}\right) ; 6.38$ (bm, 1H, H-1-phenothiazine); 6.68 (bm, 1H, H-9-phenothiazine); 6.82-6.92 (bm, 2H, H-4,7phenothiazine); 6.98 (bm, 1H, H-6-phenothiazine); 7.00 (bm, 1H, $\mathrm{H}$-2-phenothiazine); 7.12 (bm, 1H, H-8-phenothiazine); 7.35 (s, 1H, H-6); 7.69 (bs, 1H, H-2). ${ }^{13} \mathrm{C}$ NMR (150.9 MHz, $\left.\mathrm{D}_{2} \mathrm{O}\right): 37.38$ $\left(\mathrm{CH}_{3} \mathrm{~N}\right) ; 41.11\left(\mathrm{CH}_{2}-2^{\prime}\right) ; 68.40\left(\mathrm{~d}, J_{\mathrm{C}, \mathrm{P}}=4.8, \mathrm{CH}_{2}-5^{\prime}\right) ; 73.70$ $\left(\mathrm{CH}-3^{\prime}\right) ; 84.32$ (C5-C $\equiv \mathrm{C}-$ phenothiazine); 85.49 (CH-1'); 87.61 
$\left(\mathrm{d}, J_{\mathrm{C}, \mathrm{P}}=8.2, \mathrm{CH}^{-} 4^{\prime}\right) ; 94.95$ (C5-C $\equiv \mathrm{C}-$ phenothiazine); 100.04 (C-5); 105.32 (C-4a); 116.45 (CH-1-phenothiazine); 117.29 (CH-9-phenothiazine); 118.22 (C-3-phenothiazine); 124.09 (C-5a-phenothiazine); 124.62 (C-4a-phenothiazine); 125.52 (CH-7-phenothiazine); 127.64 (CH-6); 129.56 (CH-6-phenothiazine); 130.57 (CH-8-phenothiazine); 131.22 (CH-4-phenothiazine); 133.32 (CH-2-phenothiazine); 147.15 (C-9a-phenothiazine); 147.65 (C-10a-phenothiazine); 150.49 (C-7a); 153.51 (CH-2); 159.05 (C-4). ${ }^{31} \mathrm{P}\left\{{ }^{1} \mathrm{H}\right\}$ NMR (202.3 MHz, $\left.\mathrm{D}_{2} \mathrm{O}\right)$ : $-22.21\left(\mathrm{t}, J=19.2, \mathrm{P}_{\beta}\right) ;-11.00\left(\mathrm{~d}, J=19.2, \mathrm{P}_{\alpha}\right) ;-8.41(\mathrm{~d}, J=$ 19.2, $\mathrm{P}_{\gamma}$ ). MS (ESI-): $\mathrm{m} / \mathrm{z}$ (\%): 644.1 (100) [M - $\left.\mathrm{H}-\mathrm{H}_{2} \mathrm{PO}_{3}\right]$; HRMS (ESI-): calcd 724.04387 for $\mathrm{C}_{26} \mathrm{H}_{25} \mathrm{O}_{12} \mathrm{~N}_{5} \mathrm{P}_{3} \mathrm{~S}$, found 724.04273 .

\section{Biochemistry}

\section{PEX}

Single incorporation. Method A: Reaction mixture $(20 \mu \mathrm{L})$ contained temp ${ }^{\text {tempa }}(3 \mu \mathrm{M}, 1 \mu \mathrm{l}), 5^{\prime}$-(FAM)-labeled primer ${ }^{r n d}$ (3 $\mu \mathrm{M}, 1.5 \mu \mathrm{l})$, dGTP $(4 \mathrm{mM}, 0.1 \mu \mathrm{l})$, either dATP or $\mathrm{dA}^{\mathrm{XTP}}$ TP $(4 \mathrm{mM}, 1 \mu \mathrm{l})$ DNA polymerase $(0.125 \mathrm{U}$ KOD XL or $0.2 \mathrm{U}$ Vent $($ exo- $))$ and reaction buffer $(2 \mu \mathrm{l})$ supplied by the manufacturer. In the case of Pwo polymerase, 1.25 $\mathrm{U}$ of the enzyme, $0.25 \mu \mathrm{l}$ of dGTP $(4 \mathrm{mM})$ and $2 \mu$ l of either dATP or $\mathbf{d A}^{\mathbf{X T P}} \mathbf{T P}(4 \mathrm{mM})$ were used. The reaction mixture was incubated for 40 minutes at $60^{\circ} \mathrm{C}$. The PEX reaction was stopped by the addition of PAGE stop solution $[20 \mu \mathrm{L}$, formamide $(80 \%, \mathrm{v} / \mathrm{v})$, EDTA $(20 \mathrm{mM})$, bromophenol blue $(0.025 \%, \mathrm{w} / \mathrm{v})$, xylene cyanol $(0.025 \%, \mathrm{w} / \mathrm{v})$ and Milli-Q water] and heated for 2 minutes at $95{ }^{\circ} \mathrm{C}$. Samples were analyzed by use of $12.5 \%$ denaturing polyacrylamide gel electrophoresis $\left(1 \mathrm{~h}, 50{ }^{\circ} \mathrm{C}\right)$ and visualized by fluorescence imaging. Method B: PEX reactions with temp ${ }^{\text {tempC }}$ were performed in the same way as described for temp ${ }^{\text {tempa }}$ except either dCTP or $\mathbf{d C}^{\mathbf{X T P}} \mathbf{T P}(4 \mathrm{mM}, 1 \mu \mathrm{l}$ for KOD XL and VENT (exo-) polymerases and $2 \mu \mathrm{l}$ for Pwo polymerase) were used.

Multiple incorporation. The reaction mixture $(20 \mu \mathrm{L})$ contained template ${ }^{\text {rnd16 }}(3 \mu \mathrm{M}, 1 \mu \mathrm{l}), 5^{\prime}$-(FAM)-labeled primer ${ }^{\text {rnd }}$ (3 $\mu \mathrm{M}, 1.5 \mu \mathrm{l}$ ), dNTP (either natural or modified, $4 \mathrm{mM}, 1 \mu \mathrm{l}$ for KOD XL and VENT(exo-) polymerases and $2 \mu$ for Pwo polymerase), DNA polymerase (0.25 U KOD XL, $0.5 \mathrm{U}$ Vent(exo-) or 12.5 U PWO) and reaction buffer $(2 \mu \mathrm{l})$ supplied by the manufacturer. The reaction mixture was incubated for 40 minutes at $60{ }^{\circ} \mathrm{C}$. The PEX reaction was stopped by the addition of PAGE stop solution $[20 \mu \mathrm{L}$, formamide $(80 \%, \mathrm{v} / \mathrm{v})$, EDTA $(20 \mathrm{mM})$, bromophenol blue $(0.025 \%, \mathrm{w} / \mathrm{v})$, xylene cyanol $(0.025 \%, \mathrm{w} / \mathrm{v})$ and Milli-Q water] and heated for 2 minutes at $95{ }^{\circ} \mathrm{C}$. Samples were analyzed by use of $12.5 \%$ denaturing polyacrylamide gel electrophoresis $\left(1 \mathrm{~h}, 50{ }^{\circ} \mathrm{C}\right)$ and visualized by fluorescence imaging.

Kinetics of incorporation of modified dNTPs. The rate of incorporation was compared by preparation of samples with natural and modified dNTPs with various time periods. The PEX reaction mixture $(20 \mu \mathrm{l})$ was performed with $5^{\prime}$-(FAM)labeled $\operatorname{prim}^{\text {rnd }}(3 \mu \mathrm{M}, 1 \mu \mathrm{l})$, temp ${ }^{\text {temp } A}(3 \mu \mathrm{M}, 1.5 \mu \mathrm{l})$ or temp $^{\text {tempC }}(3 \mu \mathrm{M}, 1.5 \mu \mathrm{l})$, dNTPs $(4 \mathrm{mM}, 1 \mu \mathrm{l})$ with KOD XL polymerase $(0.125 \mathrm{U})$ in enzyme reaction buffer $(1 \mu \mathrm{L})$ supplied by the manufacturer, followed by stopping of the reaction by the use of PAGE stop solution [20 $\mu \mathrm{L}$, formamide (80\%, v/v), EDTA (20 $\mathrm{mM})$, bromophenol blue $(0.025 \%, \mathrm{w} / \mathrm{v})$, xylene cyanol $(0.025 \%, w / v)$ and Milli-Q water] and immediate heating for 2 minutes at $95{ }^{\circ} \mathrm{C}$. Samples were analyzed by use of $12.5 \%$ denaturing polyacrylamide gel electrophoresis $\left(1 \mathrm{~h}, 50{ }^{\circ} \mathrm{C}\right)$ and visualized by fluorescence imaging.

PCR. (A) The PCR reaction mixture $(20 \mu \mathrm{L})$ contained KOD XL (3 U), natural dNTPs $(4 \mathrm{mM}, 0.15 \mu \mathrm{l})$, modified dNTPs $(4 \mathrm{mM}, 2 \mu \mathrm{l})$, primers $(10 \mu \mathrm{M}, 4 \mu \mathrm{L}$, LT25TH: 5'-CAAGGACAAAATACCTGTATTCCTT-3' and $10 \mu \mathrm{M}, 4 \mu \mathrm{L}$, L20-: 5'-GACATCATGAGAGACATCGC-3'), and a 98-mer template $(1 \mu \mathrm{M}, 0.5 \mu \mathrm{L}$, FVL-A: 5'-GACATCATGAGAGACATCGCCTCTGGG CTAATAGGACTACTTCTAATCTGTAAGAGCAGATCCCTGGACAGG CAAGGAATACAGGTATTTTGTCCTTG-3') in reaction buffer $(2 \mu \mathrm{L})$ supplied by the manufacturer. 30 PCR cycles were run under the following conditions: denaturation for $1 \mathrm{~min}$ at $95{ }^{\circ} \mathrm{C}$, annealing for $1 \mathrm{~min}$ at $53{ }^{\circ} \mathrm{C}$, extension for $1.5 \mathrm{~min}$ at $72{ }^{\circ} \mathrm{C}$, followed by the final extension step of $2 \mathrm{~min}$ at $72{ }^{\circ} \mathrm{C}$. Reaction mixtures were than separated by use of a $2 \%$ agarose gel in $0.5 \times$ TBE buffer with GelRed as an intercalator. Visualization was performed using an electronic dual wave transilluminator equipped with a GBox iChemi XRQ Bio imaging system (Syngene).

(B) The PCR reaction mixture $(20 \mu \mathrm{L})$ contained KOD XL (3 U), natural dNTPs ( $4 \mathrm{mM}, 0.15 \mu \mathrm{l})$, primers $(10 \mu \mathrm{M}, 4 \mu \mathrm{L}$, LT25TH: 5'-CAAGGACAAAATACCTGTATTCCTT-3' and $10 \mu \mathrm{M}$, $4 \mu \mathrm{L}$, L20-: 5'-GACATCATGAGAGACATCGC-3'), and a 98-mer template $(1 \mu \mathrm{M}, 0.5 \mu \mathrm{L}$, FVL-A: 5'-GACATCATGAGAGACATCG CCTCTGGGCTAATAGGACTACTTCTAATCTGTAAGAGCAGATCC CTGGACAGGCAAGGAATACAGGTATTTTGTCCTTG-3'), in reaction buffer $(2 \mu \mathrm{L})$ supplied by the manufacturer. Modified dNTPs (either $\mathbf{d A}^{\mathbf{P T}} \mathbf{T P}$ or $\mathbf{d A}^{\mathbf{E P T}} \mathbf{T P}$ ) were added in combination with natural dATP (100\%: $\mathbf{d A}^{\mathbf{X P T}} \mathbf{T P}$ (4 mM, $\left.2 \mu \mathrm{l}\right) ; 90 \%$ : $\mathbf{d A}^{\mathbf{X P T}} \mathbf{T P}$ (4 mM, $1.8 \mu \mathrm{l}$ ), dATP (4 mM, $0.2 \mu \mathrm{l}) ; 80 \%$ : dA ${ }^{\mathbf{X P T}} \mathbf{T P}(4 \mathrm{mM}$, $1.6 \mu \mathrm{l}$ ), dATP $(4 \mathrm{mM}, 0.4 \mu \mathrm{l}) ; 50 \%$ : $\mathbf{d A}^{\mathbf{X P T}} \mathbf{T P}(4 \mathrm{mM}, 1.0 \mu \mathrm{l})$, dATP $(4 \mathrm{mM}, 1.0 \mu \mathrm{l})$ ) and 30 PCR cycles were run under the following conditions: denaturation for $1 \mathrm{~min}$ at $95{ }^{\circ} \mathrm{C}$, annealing for $1 \mathrm{~min}$ at $53{ }^{\circ} \mathrm{C}$, extension for $1.5 \mathrm{~min}$ at $72{ }^{\circ} \mathrm{C}$, followed by the final extension step of $2 \mathrm{~min}$ at $72{ }^{\circ} \mathrm{C}$. Reaction mixtures were than separated by use of a $2 \%$ agarose gel with GelRed as an intercalator. Visualization was performed using an electronic dual wave transilluminator equipped with a GBox iChemi XRQ Bio imaging system (Syngene).

(C) PCR reactions were performed in the same way as described above except 5'-(FAM)-labeled primers $(10 \mu \mathrm{M}, 4 \mu \mathrm{L}$, 5'-(FAM)-LT25TH: 5' (FAM)-CAAGGACAAAATACCTGTATTCCTT-3' and $10 \mu \mathrm{M}, 4 \mu \mathrm{L}, 5^{\prime}$-(FAM)-L20-: 5' (FAM)-GACATCATGAGAGA CATCGC-3') were used and visualization was performed by fluorescence imaging.

TdT elongation. The reaction mixture $(10 \mu \mathrm{L})$ contained $\mathrm{TdT}$ (12 U), dATP, $\mathbf{d A}^{\mathbf{P T}} \mathbf{T P}$, or $\mathbf{d} \mathbf{A}^{\mathbf{E P T}} \mathbf{T P}(4 \mathrm{mM}, 1 \mu \mathrm{l})$ and $5^{\prime}$-FAM labeled primer ${ }^{r n d}(3 \mu \mathrm{M}, 0.5 \mu \mathrm{l})$ in enzyme reaction buffer $(1 \mu \mathrm{L})$ supplied by the manufacturer. The reaction mixture was incubated for 1 or $4 \mathrm{~h}$ at $37^{\circ} \mathrm{C}$ in a thermal cycler. Before gel loading, samples were denatured by the addition of $10 \mu \mathrm{L}$ of stop solution $(80 \%[\mathrm{v} / \mathrm{v}]$ formamide, $20 \mathrm{mM}$ EDTA, $0.025 \%$, 
$[\mathrm{w} / \mathrm{v}]$ bromophenol blue, $0.025 \%[\mathrm{w} / \mathrm{v}]$ xylene cyanol, and Milli-Q water) and heated for $10 \mathrm{~min}$ at $95{ }^{\circ} \mathrm{C}$. Reaction mixtures were separated by using $12.5 \%$ denaturing PAGE. Visualization was performed by fluorescence imaging.

\section{NEAR}

NEAR general procedure. The reaction mixture contained the template $(0.125 \mu \mathrm{M})$, primer $(0.125 \mu \mathrm{M})$, modified $\mathbf{d N}^{\mathbf{x}} \mathbf{T P}$ $(160 \mu \mathrm{M})$, natural dNTPs $(125 \mu \mathrm{M}), 1 \times$ ThermoPol buffer $\left(10 \mathrm{mM} \mathrm{KCl}, 10 \mathrm{mM}\left(\mathrm{NH}_{4}\right)_{2} \mathrm{SO}_{4}, 20 \mathrm{mM}\right.$ Tris-HCl/pH 8.8/, $0.1 \%$ Triton-X-100, and $2 \mathrm{mM} \mathrm{MgSO}_{4} ; 5 \mu \mathrm{L}$ for analytical scale and $50 \mu \mathrm{L}$ for preparative scale), and $0.5 \times$ NEBuffer 3 (50 mM NaCl, $25 \mathrm{mM}$ Tris- $\mathrm{HCl} / \mathrm{pH} 7.9,5 \mathrm{mM} \mathrm{MgCl}_{2}$, and $0.5 \mathrm{mM}$ DTT; $2.5 \mu \mathrm{L}$ for analytical scale and $25 \mu \mathrm{L}$ for preparative scale), Vent(exo-) (5 U for analytical scale and $80 \mathrm{U}$ for preparative scale), Nt.BstNBI (30 U for analytical scale and $150 \mathrm{U}$ for preparative scale). The reaction mixture was incubated at $55{ }^{\circ} \mathrm{C}$ for $3 \mathrm{~h}$. The reaction was stopped by cooling to $4{ }^{\circ} \mathrm{C}$.

NEAR on analytical scale. The analytical reactions were performed according to the general procedure in a volume of $50 \mu \mathrm{L}$. The products were analyzed by agarose gel electrophoresis using $4 \%$ agarose gels stained with GelRed (Lab Mark). Samples were prepared by mixing $1.6 \mu \mathrm{L}$ of $6 \times$ DNA Loading Dye (Thermo Scientific) and $8 \mu \mathrm{L}$ of the reaction mixture or ss DNA ladder. The gel was run for $70 \mathrm{~min}$ at $120 \mathrm{~V}$ and imaged using an electronic dual wave transilluminator equipped with a GBox iChemi XRQ Bio imaging system (Syngene).

NEAR on preparative scale. The preparative reactions were performed according to the general procedure in a volume of $500 \mu \mathrm{L}$. After the reaction was stopped, the solution was concentrated on a vacuum concentrator to approximately $100 \mu \mathrm{L}$. The viscous concentrate was injected on an HPLC XBridge OST C18 Column (waters; $2.5 \mu \mathrm{m}$ particle size, $4.6 \mathrm{~mm} \times$ $50 \mathrm{~mm}$ ) and separated using a gradient of triethylammonium acetate (TEAA) and acetonitrile at a flow rate of $1 \mathrm{~mL} \mathrm{~min}^{-1}$. Mobile phase A corresponded to 0.1 M TEAA in HPLC-grade water and mobile phase B to acetonitrile/0.1 M TEAA in HPLC grade water $20 / 80(\mathrm{v} / \mathrm{v})$. The fractions containing the product were evaporated on a vacuum concentrator. The products were analyzed by MALDI-TOF mass spectrometry.

MALDI-TOF. The MALDI-TOF spectra were measured with $1 \mathrm{kHz}$ smartbeam II laser technology. The measurements were made in reflectron mode by the droplet technique, with mass range up to $30 \mathrm{kDa}$. The matrix consisted of 3-hydroxypicolinic acid (HPA)/picolinic acid (PA)/ammonium tartrate in a 9/1/1 ratio. The matrix $(1 \mu \mathrm{L})$ was applied on the target (ground steel) and dried down at room temperature. The sample $(1 \mu \mathrm{L})$ and matrix $(1 \mu \mathrm{L})$ were mixed and added on top of the dried matrix preparation spot and dried at room temperature. The reaction mixture $(50 \mu \mathrm{L})$ contained biotinylated temp $p^{\text {rnd16 }}$ $\left(\right.$ temp $^{A}$ or temp $\left.{ }^{C}\right)(100 \mu \mathrm{M}, 1.6 \mu \mathrm{L})$, primer ${ }^{r n d}(100 \mu \mathrm{M}, 1.6 \mu \mathrm{L})$, dNTPs $(4 \mathrm{mM}, 2.6 \mu \mathrm{L})$, and KOD XL polymerase $(1.25 \mathrm{U}$; in the case of multiple incorporation of two different modified $\mathrm{dN}^{\mathrm{x}}$ TPs $2.5 \mathrm{U}$ of KOD XL polymerase was used) in enzyme reaction buffer $(5 \mu \mathrm{L})$ supplied by the manufacturer. The reaction mixture was incubated for $40 \mathrm{~min}$ at $60^{\circ} \mathrm{C}$ in a thermal cycler. The reaction was stopped by cooling to $4{ }^{\circ} \mathrm{C}$.

Streptavidin magnetic particles (Roche, $50 \mu \mathrm{L}$ ) were washed with binding buffer TEN100 (10 mM Tris, $1 \mathrm{mM}$ EDTA, $100 \mathrm{mM} \mathrm{NaCl}, \mathrm{pH} 7.5 ; 3 \times 200 \mu \mathrm{L}$ ). The reaction mixture after PEX was diluted with binding buffer TEN100 $(50 \mu \mathrm{L})$, and then the solution was added to the prewashed magnetic beads and incubated for $30 \mathrm{~min}$ at $15{ }^{\circ} \mathrm{C}$ and $1400 \mathrm{rpm}$. After the incubation, the magnetic beads were collected on a magnet (DynaMag-2, Invitrogen) and the solution was discarded. The beads were washed successively with wash buffer TEN 500 (10 mM Tris, $1 \mathrm{mM}$ EDTA, $500 \mathrm{mM} \mathrm{NaCl}, \mathrm{pH} 7.5 ; 3 \times 200 \mu \mathrm{L}$ ), and water $(3 \times 200 \mu \mathrm{L})$. Then water $(50 \mu \mathrm{L})$ was added and the sample was denatured for $2 \mathrm{~min}$ at $55{ }^{\circ} \mathrm{C}$ and $900 \mathrm{rpm}$. The beads were collected on a magnet and the solution was transferred into a clean vial. The product was analyzed by MALDI-TOF mass spectrometry.

\section{Electrochemistry}

Nucleosides and free PT were analyzed by conventional in situ cyclic or square wave voltammetry (CV or SWV). Purified NEAR and PEX products were analyzed by $e x$ situ (adsorptive transfer stripping) SWV. The NEAR and PEX products were accumulated at the surface of the working basal-plane pyrolytic graphite electrode for $60 \mathrm{~s}$ from $5 \mu \mathrm{L}$ aliquots containing $0.2 \mathrm{M}$ $\mathrm{NaCl}$. The electrode was then rinsed with deionized water and placed in the electrochemical cell. CV settings: initial potential $\left(E_{\mathrm{i}}\right) 0.0 \mathrm{~V}$, for switching potential $\left(E_{\mathrm{sw}}\right)$ see legends in Fig. 7, scan rate $1 \mathrm{~V} \mathrm{~s}^{-1}$, SWV settings: initial potential $0.0 \mathrm{~V}$, end potential $1.5 \mathrm{~V}$, frequency $200 \mathrm{~Hz}$, amplitude $50 \mathrm{mV}$. Background electrolyte: $0.2 \mathrm{M}$ sodium acetate $\mathrm{pH}$ 5.0. All measurements were performed at room temperature using an Autolab analyzer (Eco Chemie, The Netherlands) in connection with a VA-stand 663 (Metrohm, Herisau, Switzerland). The three-electrode system was used with an $\mathrm{Ag}|\mathrm{AgCl}| 3 \mathrm{M} \mathrm{KCl}$ electrode as the reference and platinum wire as the auxiliary electrode.

\section{Acknowledgements}

This work was supported by the Academy of Sciences of the Czech Republic (RVO: 61388963, Praemium Academiae award for M. H.), by the Czech Science Foundation (P206-12-G151 to A. S., L. H., M. F. and M. H.).

\section{References}

1 E. Paleček and M. Bartošík, Chem. Rev., 2012, 112, 34273481.

2 M. Hocek and M. Fojta, Chem. Soc. Rev., 2011, 40, 58025814.

3 D. A. Di Giusto, W. A. Wlassoff, S. Giesebrecht, J. J. Gooding and G. C. King, J. Am. Chem. Soc., 2004, 126, 4120-4121. 
4 P. Brázdilová, M. Vrábel, R. Pohl, H. Pivonková, L. Havran, M. Hocek and M. Fojta, Chem. - Eur. J., 2007, 13, 9527-9533.

5 H. Cahová, L. Havran, P. Brázdilová, H. Pivonková, R. Pohl, M. Fojta and M. Hocek, Angew. Chem., Int. Ed., 2008, 47, 2059-2062.

6 M. Vrábel, P. Horáková, H. Pivonková, L. Kalachova, H. Cernocká, H. Cahová, R. Pohl, P. Sebest, L. Havran, M. Hocek and M. Fojta, Chem. - Eur. J., 2009, 15, 11441154.

7 J. Balintová, R. Pohl, P. Horáková, P. Vidláková, L. Havran, M. Fojta and M. Hocek, Chem. - Eur. J., 2011, 17, 1406314073.

8 A. A. Gorodetsky, O. Green, E. Yavin and J. K. Barton, Bioconjugate Chem., 2007, 18, 1434-1441.

9 J. Balintová, M. Plucnara, P. Vidláková, R. Pohl, L. Havran, M. Fojta and M. Hocek, Chem. - Eur. J., 2013, 19, 1272012731.

10 J. Balintová, J. Špaček, R. Pohl, M. Brázdová, L. Havran, M. Fojta and M. Hocek, Chem. Sci., 2015, 6, 575587.

11 P. Dauphin-Ducharme and K. W. Plaxco, Anal. Chem., 2016, 88, 11654-11662.

12 A. M. Debela, S. Thorimbert, B. Hasenknopf, C. K. O'Sullivan and M. Ortiz, Chem. Commun., 2016, 52, 757-759.

13 A. M. Debela, M. Ortiz, V. Beni, S. Thorimbert, D. Lesage, R. B. Cole, C. K. O'Sullivan and B. Hasenknopf, Chem. Eur. J., 2015, 21, 17721-17727.

14 A. Simonova, J. Balintová, R. Pohl, L. Havran, M. Fojta and M. Hocek, ChemPlusChem, 2014, 79, 1703-1712.

15 L. A. Tinker and A. J. Bard, J. Am. Chem. Soc., 1979, 101, 2316-2319.

16 B. Paduszek and M. K. Kalinowski, Electrochim. Acta, 1983, 28, 639-642.

17 A. M. M. Rawashdeh, Basic Sci. Eng., 2005, 14, 195-208.

18 A. A. Golriz, T. Kaule, M. B. Untch, K. Kolman, R. Berger and J. S. Gutmann, ACS Appl. Mater. Interfaces, 2013, 5, 2485-2494.
19 N. Nakadan, S. Imabayashi and M. Watanabe, J. Electroanal. Chem., 2009, 632, 59-63.

20 G. Viola, L. Latterini, D. Vedaldi, G. G. Aloisi, F. Dall'Acqua, N. Gabellini, F. Elisei and A. Barbafina, Chem. Res. Toxicol., 2003, 16, 644-651.

21 M. T. Tierney and M. W. Grinstaff, Org. Lett., 2000, 2, 34133416.

22 M. T. Tierney and M. W. Grinstaff, J. Org. Chem., 2000, 65, 5355-5359.

$23 \mathrm{X} . \mathrm{Hu}, \mathrm{M}$. T. Tierney and M. W. Grinstaff, Bioconjugate Chem., 2002, 13, 83-89.

24 S. A. N. Hashmi, X. Hu, C. E. Immoos, S. J. Lee and M. W. Grinstaff, Org. Lett., 2002, 4, 4571-4574.

25 M. Hocek, J. Org. Chem., 2014, 79, 9914-9921.

26 A. Hottin and A. Marx, Acc. Chem. Res., 2016, 49, 418-427.

27 P. Kielkowski, J. Fanfrlík and M. Hocek, Angew. Chem., Int. Ed., 2014, 53, 7552-7555.

28 H. Cahová, A. Panattoni, P. Kielkowski, J. Fanfrlík and M. Hocek, ACS Chem. Biol., 2016, 11, 3165-3171.

29 A. Hottin, K. Betz, K. Diederichs and A. Marx, Chem. - Eur. J., 2017, 23, 2109-2118.

30 F. Seela, A. Zulauf, H. Rosemeyer and H. Reuter, J. Chem. Soc., Perkin Trans. 2, 1996, 2373-2376.

31 K. H. Shaughnessy, Molecules, 2015, 20, 9419-9454.

32 P. Ménová, V. Raindlová and M. Hocek, Bioconjugate Chem., 2013, 24, 1081-1093.

33 J. Van Ness, L. K. Van Ness and D. J. Galas, Proc. Natl. Acad. Sci. U. S. A., 2003, 100, 4504-4509.

34 A. M. Michelson and S. H. Orkin, J. Biol. Chem., 1982, 257, 14773-14782.

35 P. Horáková, H. Macíčková-Cahová, H. Pivoňková, J. Spaček, L. Havran, M. Hocek and M. Fojta, Org. Biomol. Chem., 2011, 9, 1366-1371.

36 H. Pivonkova, P. Horakova, M. Fojtova and M. Fojta, Anal. Chem., 2010, 82, 6807-6813.

37 C. S. Kramer and T. J. J. Muller, Eur. J. Org. Chem., 2003, 3534-3548.

38 C. S. Kramer, T. J. Zimmermann, M. Sailer and T. J. J. Muller, Synthesis, 2002, 1163-1170. 